\title{
Recent Advances in $\omega$-Transaminase-Mediated Biocatalysis for the Enantioselective Synthesis of Chiral Amines
}

\author{
Mahesh D. Patil ${ }^{1}$, Gideon Grogan ${ }^{2}$, Andreas Bommarius ${ }^{3}$ (i) and Hyungdon Yun ${ }^{1, *}$ \\ 1 Department of Systems Biotechnology, Konkuk University, 120 Neungdong-ro, Gwangjin-gu, Seoul 05029, \\ Korea; mahi1709@gmail.com \\ 2 Department of Chemistry, University of York, Heslington, York YO10 5DD, UK; gideon.grogan@york.ac.uk \\ 3 School of Chemical \& Biomolecular Engineering, Georgia Institute of Technology, 311 Ferst Drive, Atlanta, \\ GA 30332-0100, USA; andreas.bommarius@chbe.gatech.edu \\ * Correspondence: hyungdon@konkuk.ac.kr
}

Received: 24 May 2018; Accepted: 19 June 2018; Published: 21 June 2018

check for updates

\begin{abstract}
Chiral amines are important components of $40-45 \%$ of small molecule pharmaceuticals and many other industrially important fine chemicals and agrochemicals. Recent advances in synthetic applications of $\omega$-transaminases for the production of chiral amines are reviewed herein. Although a new pool of potential $\omega$-transaminases is being continuously screened and characterized from various microbial strains, their industrial application is limited by factors such as disfavored reaction equilibrium, poor substrate scope, and product inhibition. We present a closer look at recent developments in overcoming these challenges by various reaction engineering approaches. Furthermore, protein engineering techniques, which play a crucial role in improving the substrate scope of these biocatalysts and their operational stability, are also presented. Last, the incorporation of $\omega$-transaminases in multi-enzymatic cascades, which significantly improves their synthetic applicability in the synthesis of complex chemical compounds, is detailed. This analysis of recent advances shows that $\omega$-transaminases will continue to provide an efficient alternative to conventional catalysis for the synthesis of enantiomerically pure amines.
\end{abstract}

Keywords: biocatalysis; chiral amines; $\omega$-transaminases; protein engineering; reaction engineering; multi-enzymatic cascades

\section{Introduction}

Enantiomerically pure amines are indispensable constituents of various small molecule pharmaceuticals, fine chemicals, and agrochemicals [1]. The increasing demands for enantiopure compounds in the pharmaceutical, fine chemicals, and agricultural industries, together with the environmental restrictions approved by many economies, require the effective integration of traditional chemical synthesis methods with those of enzymatic 'greener' approaches [2-5]. The chemical synthesis of chiral amines is labor intensive, requiring harsh reaction conditions and use of toxic intermediates. The use of toxic metals also warrants a purification step, thus further complicating the synthetic systems and the cost thereof [6]. As enzymes are obtained from renewable resources, they fulfil the basic demands of sustainable and green chemistry, proposed by Graedel et al. [7]. In this context, biocatalysis, the application of enzymes for efficient and selective chemical transformations, has been recognized as a major 'green technology' that provides sustainable synthetic methods towards a range of chiral compounds [8,9]. 
Transaminases (TAs) are one of the largest groups of enzymes used in the synthesis of chiral amine building blocks [10-13]. As TAs play key roles in various cellular signaling and metabolic pathways, their presence is ubiquitous in nature [14]. The history of transamination can be traced back to 1930, when Needham and coworkers observed the relationship between levels of amino acids such as L-glutamic acid, L-aspartic acid and oxaloacetic acid in the breast muscles of pigeon [15]. Since the first demonstration of transamination in the late 1930s, various transaminases have been discovered in subsequent decades $[16,17]$. Depending on their specificities towards various substrates, transaminases are generally classified as $\alpha$ - or $\omega$-TAs. Transaminases are classified based on the structures of the amino donor substrates, which are divided based on the presence and position of a negatively charged group with respect to the amino group being transferred. In the case of $\alpha$-Transaminases (i.e., amino acid TAs), the presence of a carboxylic acid group in the $\alpha$-position to the keto or amine functionality is exclusively required [18]. $\omega$-TAs transfer an amino group attached to a primary carbon at least one carbon away from a carboxyl group (Figure 1). In addition, compounds lacking any carboxyl groups, such as amines and ketones, can serve as substrates for $\omega$-TAs, thus making these enzymes potential biocatalysts for the synthesis of chiral amine compounds [18-20]. $\omega$-TAs accepting amines/ketones without carboxylic group are interchangeably referred to as amino transaminases.

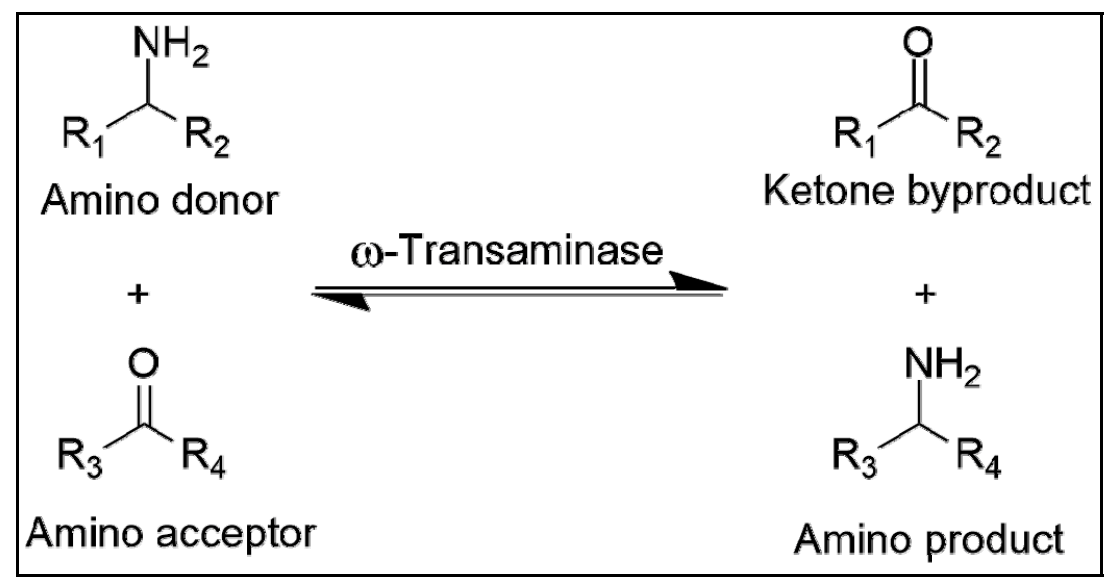

Figure 1. Schematic of transamination catalyzed by transaminases.

The mechanism of the $\omega$-TA-catalyzed transamination reaction is well studied and has been reported to exhibit ping-pong-bi-bi kinetics. In a two-step reaction, Pyridoxal 5'-phosphate (PLP), bound to the lysine residue of an enzyme, mediates the transfer of amino group from an amino donor, such as L-alanine to form pyridoxamine phosphate (PMP) intermediate. Subsequently, this amine group is transferred to the amino acceptor, such as a keto acid or ketone and the PLP is regenerated for the next catalytic cycle $[12,18,21]$. The enantiomeric purity of the stereospecific isomer formed by TA-mediated biocatalysis is a consequence of their exclusive substrate-binding mode, which is constrained by the relative position of PLP and two substrate-binding pockets of different sizes.

PLP-dependent enzymes are divided into seven Fold-Types (I-VII) and despite their wide substrate specificities, $\omega$-transaminases are only found in two different protein folds: $(S)$-selective enzymes, which belong to protein fold-type I and $(R)$-selective enzymes belonging to protein fold-type IV) $[19,20,22]$.

\section{Synthetic Approaches for Chiral Amines and Equilibrium Shift for $\omega$-TA-Mediated Biocatalysis}

$\omega$-TAs can be employed for the synthesis of enantiopure amines using three approaches: (A) kinetic resolution of the racemic mixture of amines; (B) asymmetric synthesis using pro-chiral ketones and (C) deracemization of racemic amines (Figure 2). The previous two decades have seen a surge of interest in TA-mediated amination reactions. 


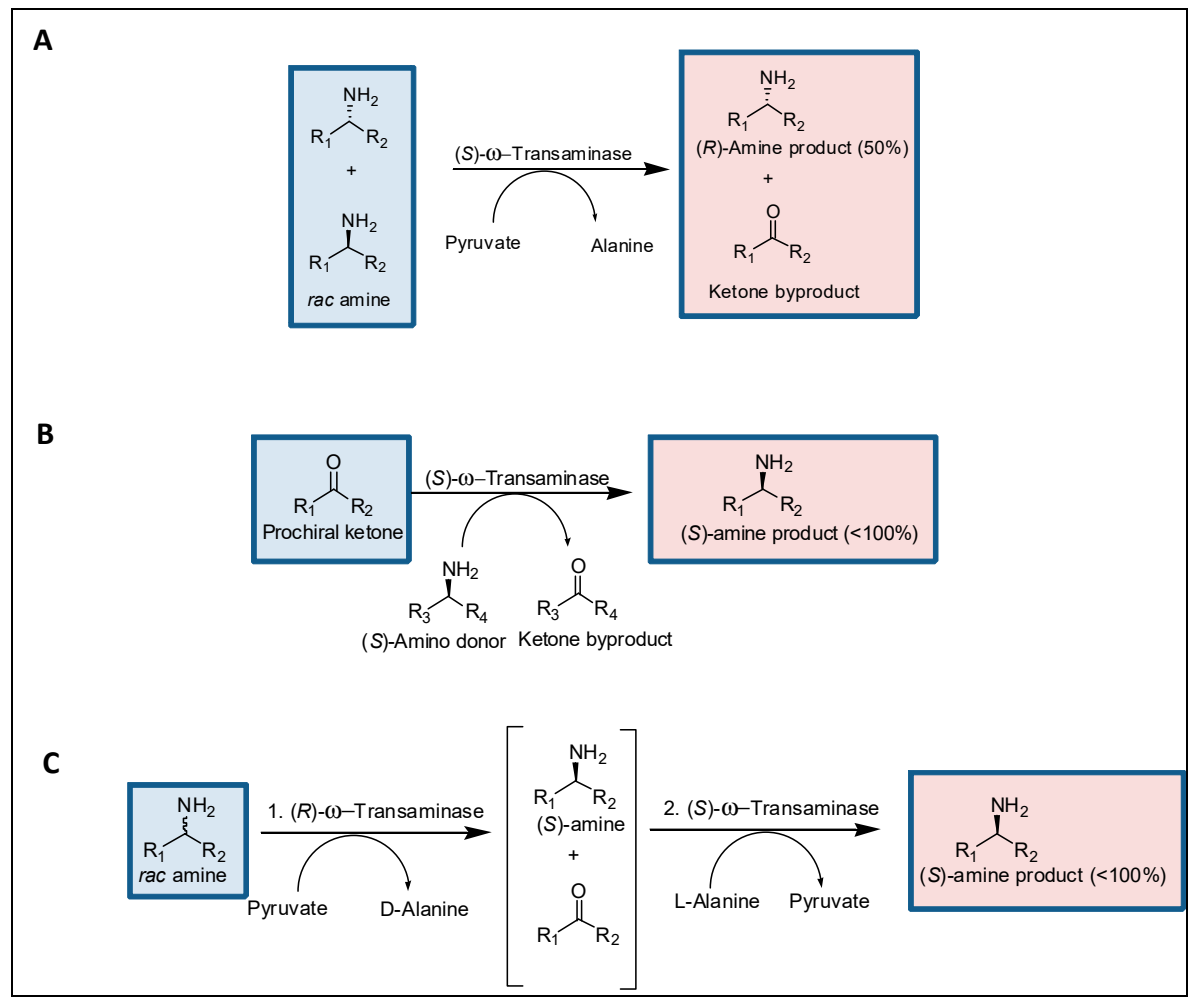

Figure 2. Synthetic approaches for $\omega$-TA-mediated amine synthesis: (A) Kinetic resolution with (S)- $\omega$-TA; (B) Asymmetric synthesis and (C) Deracemization of racemic amine using $(R)$ - $\omega$-TA and (S)-w-TA. (Adapted from [14], Copyright (2010), with permission from Elsevier).

\subsection{Kinetic Resolution}

The kinetic resolution of primary amines employs stoichiometric amounts of an amino acceptor, wherein the reaction equilibrium favors product formation. Since the early 1990s, when Celgene Corporation successfully used kinetic resolution for the synthesis of enantiopure amines [23], this approach has been extensively explored in the last few years [15,24-28].

With the developing substrate scope and improved enzymatic characteristics, many "ready to use" screening toolkits are commercially available for their application in biocatalysis. For instance, commercially available $\omega$-TAs from Codexis such as ATA-256, ATA-114, ATA-117, ATA-113, and ATA-103 have been successfully applied for the synthesis of chiral amines [12,29,30]. In addition, a new pool of potential TAs is being continuously screened and characterized from various microbial strains [31,32]. Recently, an (S)- $\omega$-transaminase from the thermophilic eubacterium Sphaerobacter thermophilus was expressed and functionally characterized in Yun's laboratory [33]. This thermostable enzyme was used for the kinetic resolution of various amines, and $\beta$ - and $\gamma$-amino acids, in the presence of pyruvate as amino acceptor. Wu et al. have characterized four new distinct $\omega$-TAs from Pseudomonas putida NBRC 14164, which were utilized for the kinetic resolution of racemic amines such as 4-phenylbutan-2-amine, 2,3-dihydro-1H-inden-1-amine and amino alcohols such as 2-amino-2-phenylethanol, 2-aminobutan-1-ol, etc. [24]. More recently, Iglesias et al. [34] characterized an (R)- $\omega$-TA from Caproniasemi immersa. In their studies, whole cell extracts of $E$. coli BL21 (DE3) expressing $(R)$ - $\omega$-TA were utilized for the resolution of several racemic amines in the presence of pyruvic acid as an amine acceptor. Most recently, Baud et al. used a metagenomics approach for the discovery of new $\omega$-TAs and subsequently for the synthesis of allylic amines [35]. Three enzymes were selected among the 11 putative class-III TAs identified by genome mining. These enzymes were further evaluated for their transamination potential of functionalized cinnamaldehydes, which are ultimately used as building blocks for antifungal Naftin ${ }^{\circledR}$ (naftifine) and analogs thereof [35]. Gao et al. also identified and characterized a novel 
$(R)$-enantioselective $\omega$-TA from Fusarium oxysporum by genome mining and evaluated it for the kinetic resolution of amine substrates, such as 1-(3-chlorophenyl)ethanamine, 1-(2-fluorophenyl)ethanamine and (4-chlorophenyl)(phenyl)methanamine [36].

Although kinetic resolution is advantageous in requiring only a single enzyme, the atom efficiency of kinetic resolution remains low with a maximum theoretical yield of 50\% [15]. The kinetic resolution also suffers other disadvantages, such as the formed ketone-product from corresponding amines being reported to cause severe inhibition [14]. Thus, the removal of formed ketone to circumvent product inhibition is highly desirable (Figure 3(AI)). Various strategies, such as physical extraction/vaporization, are available to remove the ketone products and thus to shift the equilibrium of the reversible reaction towards product formation [37] (Figure 3). Accordingly, isopropylamine has been identified as an industrial choice, since it is readily available and economically viable, and its product acetone is volatile and can easily be removed by reduced pressure (Figure 3(AII)) [34,38,39]. However, complete removal of low concentrations of acetone $(<100 \mathrm{mM})$, without removing other volatile components of the reaction, is a challenging task.

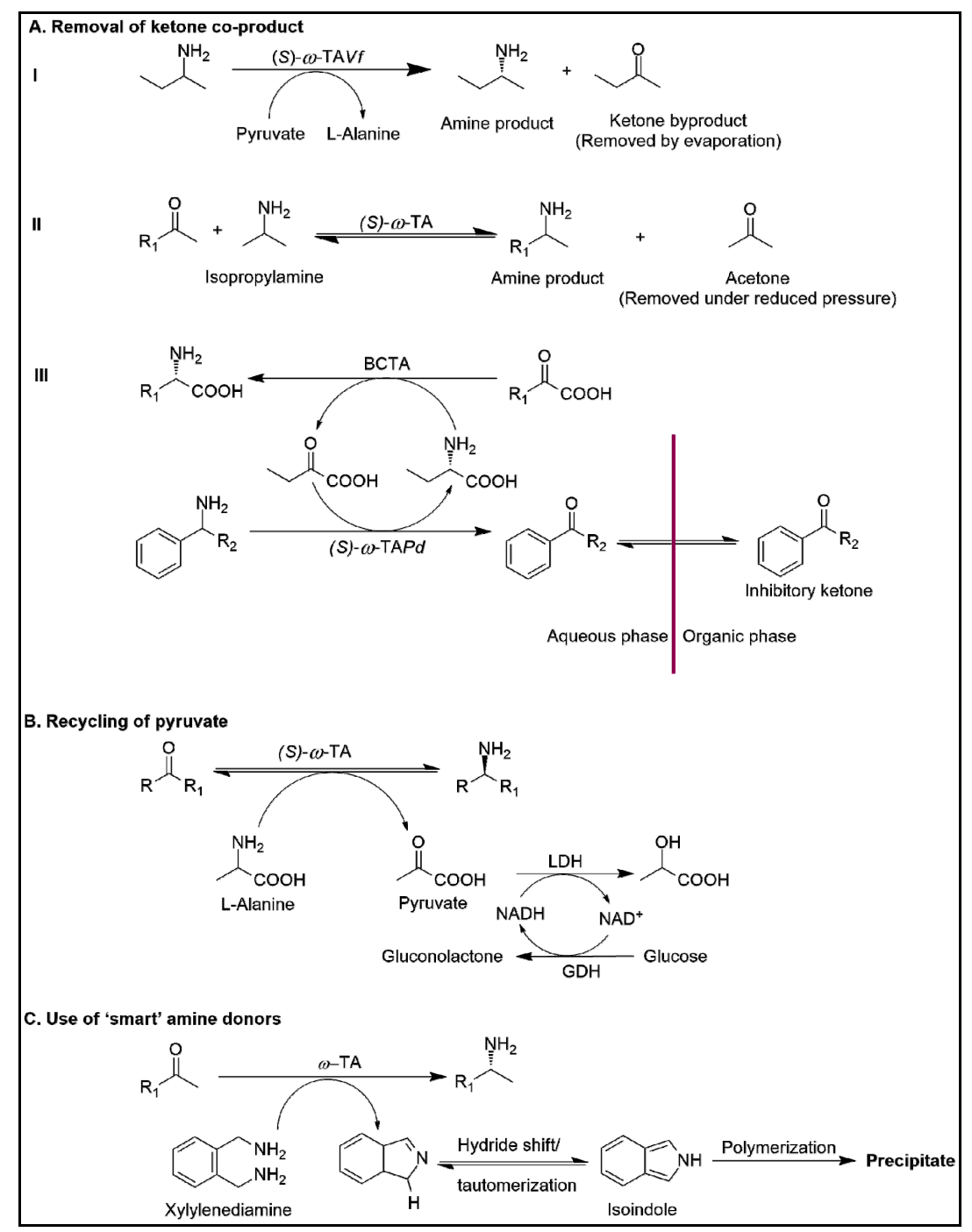

Figure 3. Various strategies used to shift the equilibrium of $\omega$-TA mediated transamination: (AI) Removal of ketone byproduct by evaporation; (AII) Removal of ketone byproduct under reduced pressure; (AIII) Removal of ketone byproduct using biphasic reaction system; (B) Recycling of pyruvate substrate; and (C) Use of 'smart' amine donors (BCTA- Branched-chain amino acid transaminases; LDH-Lactate dehydrogenase; GDH-Glucose dehydrogenase). 
It has also been reported that the removal of ketones by physical methods is critically affected by the equilibrium constant and volatility of the ketones. Owing to the differential polarities of amines and ketones, methods such as extraction using bi-phasic reactions systems, either liquid-solid or liquid-liquid, have been developed for the continuous removal of ketone products (Figure 3(AIII)) [40]. However, extraction using organic/aqueous biphasic systems is limited by the denaturation of enzymes in an organic environment and the poor discrimination between substrate and product [12]. Nonetheless, to avoid enzyme denaturation in biphasic systems, stabilization of enzymes by immobilization [41,42] (detailed in Section 4.3), enzyme membrane- and packed bed reactors have also been reported $[15,43,44]$.

\subsection{Asymmetric Synthesis}

The maximum theoretical yield of 50\% limits the practical applications of the kinetic resolution approach. Thus, despite being more challenging than kinetic resolution, asymmetric synthesis and deracemization are preferred strategies, as they can generate a theoretical yield of $100 \%$ [45]. In asymmetric synthesis, prochiral ketones are aminated to the corresponding chiral amines, with the possibility of obtaining the desired enantiopure amine form in 100\% yield [14].

Other than an industrially applied procedure for antidiabetic Sitagliptin, the recent successful examples of amine synthesis by $\omega$-TA-mediated catalysis include pyridyl alkylamines [46], (R)-ramatroban precursor [47] and serinol [48]. Moreover, substituted aminotetralins, potential agents used to treat Parkinson's disease and cardiovascular disorders, have also been successfully synthesized using an engineered $\omega$-TA from Arthrobacter citreus [ $\omega$-TAAc] [49] and a novel (S)-selective $\omega$-TA from Pseudomonas fluorescens KNK08-18 [50]. However, $\omega$-TA-mediated transamination reactions generally are thermodynamically limited [51]. For instance, the reported equilibrium constant of $\omega$-TA from Vibrio fluvialis JS17 ( $\omega$-TAVf) for the kinetic resolution of (S)- $\alpha$-MBA, using pyruvate as co-substrate, is 1135. Thus, the equilibrium is greatly shifted toward the formation of L-alanine and acetophenone, consequently making it difficult to perform asymmetric synthesis of (S)- $\alpha$-MBA without rapid product removal and/or the use of sacrificial amines as donors [52].

Subsequently, various strategies have been applied to prevail over these limitations. For instance, a 20-fold excess of (S)- $\alpha$-MBA was used in the asymmetric synthesis of serinol-monoester, a precursor for the synthesis of chloramphenicol, wherein the (S)-enantiomer was obtained with $92 \%$ conversion and $92 \% e e$, when F85L/V153A variant of $\omega$-TAVf was used [48]. In addition, many of the $\omega$-TAs use L-alanine as an amine donor. Thus, the recycling or removal of pyruvate formed can help to overcome the thermodynamic barrier of the reaction. The application of two strategies is generally used for the removal of pyruvate co-product. (1) Use of lactose dehydrogenase (LDH) and NADH recycling system [53], wherein pyruvate is reduced to lactate, which is recycled using glucose dehydrogenase at the expense of cheaper substrate i.e., glucose (Figure 3B). (2) Use of alanine dehydrogenase (AlaDH) for the effective recycling of L-alanine as amine donor has been reported to reduce the cost of amine donor by $97 \%$, while simultaneously decreasing the E-factor (environmental factor; the ratio of the mass of waste per mass of product) and improving the atom efficiency [54]. However, the use of additional enzymes and their cofactors leads to further complications of the overall biocatalytic reactions.

Although $\alpha$-MBA, isopropylamine and L-alanine have been most frequently used as amine donors in the $\omega$-TA-mediated asymmetric syntheses, more reactive amine donors are highly desirable to drive reaction equilibrium, and to reduce the use of a high molar excess of these sacrificial amine donors used in the biocatalytic reactions. Recently, 'smart' diamine donors, such as xylylenediamine (XDA) were discovered, which is readily converted to an amino aldehyde. The subsequent intramolecular cyclization of the amino aldehydes tautomerizes to form isoindol, which is polymerized, and can easily be removed from the reaction mixture due to precipitation (Figure 3C) [53]. However, XDA is not accepted by all wild-type $\omega$-TAs, and it is not a cheaper amino donor, ultimately increasing the cost of the biocatalytic reaction [30]. It was more recently reported that only 1.5 equiv. of cis-but-2-ene-1,4-diamine can be used as sacrificial amine donor for the conversion of aromatic 
sec-alcohols with different substitutions in the aromatic ring to the corresponding amines in a sequential application of laccases and $\omega$-TAs [55]. Furthermore, recyclable biogenic terminal diamines, such as putrescine, cadaverine, and spermidine have also recently been discovered to drive the equilibrium towards amination of ketones. Following the transamination, these bio-based diamines are converted into reactive amino aldehydes, which spontaneously get converted to cyclic imines, thus shifting the equilibrium towards product formation [56].

The synthesis of chiral amines using $\omega$-TA-mediated catalysis has been explored using broad substrate types, including linear, cyclic and aromatic ketones. Numerous research groups have exploited this biocatalytic route for the synthesis of a wide range of pharmaceutical compounds, their intermediates and unnatural amino acids such as beta-and gamma-amino acids [33,57]. Various methods, for instances, co-product removal using cascade enzymes, and the use of 'smart' amine donors to reduce the excess use of sacrificial amines, have been developed to overcome the limitations in biocatalytic reactions employing $\omega$-TAs. Recently, Rehn et al. demonstrated the successful use of supported liquid membrane for the in-situ product removal of $(S)$ - $\alpha$-methylbenzylamine (MBA) produced by immobilized $\omega$-TAAc [58]. Other strategies, such as substrate engineering [59] and protein engineering, have also been developed for the efficient synthesis of chiral amines by $\omega$-TA-mediated biocatalysis.

\subsection{Deracemization}

While asymmetric synthesis is still the most favored approach to biocatalytic amine synthesis, deracemization is also attractive, especially when access to racemic amines as substrates is easier than to the corresponding prochiral ketone. In a deracemization reaction, theoretical complete conversion and enantioselectivity is achieved by employing two stereocomplementary $\omega$-TAs. The first step in the deracemization process affords the formation of $\leq 50 \%$ enantiopure amine and the corresponding ketone co-product by enantioselective deamination of the racemic amine. This is followed by the asymmetric amination of the ketone by an enantiocomplementary $\omega$-TA, forming the optically pure amine in up to $100 \%$ yield [17]. Deracemization has been effectively used for the synthesis of important pharmaceutical drugs, such as mexiletine, an orally effective anti-arrhythmic drug (Figure 4) [60,61]. In this one-pot two-step process on $100 \mathrm{mg}$ scale, an isolated yield of $97 \%$ with excellent enantioselectivity ( $>99 \%$ ee) could be achieved by the combination of two stereocomplementary enzymes [61]. In addition, the change in an absolute configuration of the generated product could easily be achieved and both $(R)$ - and $(S)$-enantiomers can be produced by this method, notably without compromising the isolated yield or enantioselectivity, by switching the order of transaminases applied.

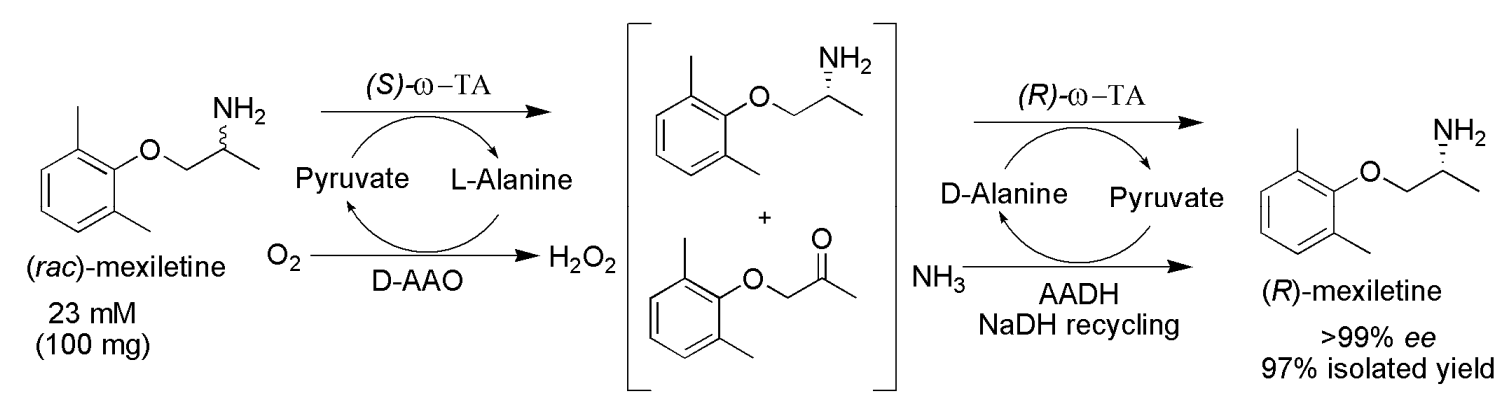

Figure 4. Use of a deracemization strategy for the synthesis of enantiopure Mexiletine (reprinted with permission from [61], Copyright (2009) American Chemical Society). (Reaction conditions: $50 \mathrm{mM}$ racemic substrate, $50 \mathrm{mM}$ sodium pyruvate, $20 \mathrm{mg}$ whole cells of E. coli expressing $\omega$-TAs, phosphate buffer (100 mM, pH 7.0), $\left.1 \mathrm{mM} \mathrm{PLP,} 30^{\circ} \mathrm{C}, 24 \mathrm{~h}\right)$. 
The application of $\omega$-TAs in dynamic kinetic resolutions has also been reported to be very effective for the synthesis of production of Niraparib, a potential anti-cancer drug, and the smoothened receptor inhibitor (SMO), used in the treatment of leukemia [62,63]. Deracemization of various important amines such as 4-phenylbutan-2-amine, a precursor for the antihypertensive dilevalol; sec-butylamine, 1-methoxy-2-propanamine and 1-cyclohexylethylamine, precursors of inhibitors of tumour necrosis factor- $\alpha$ (TNF- $\alpha$ ); and 1-phenyl-1-propylamine, a precursor of anti-depressant agent corticotropin releasing factor type-1 receptor antagonist, and other important aromatic amines has been reported in the literature $[64,65]$.

\section{Protein Engineering Aspects for Improved Substrate Scope of $\omega$-Transaminase ( $\omega$-TA) Biocatalysts}

In the context of $\omega$-TAs, the scientific community has used various protein engineering aspects for the efficient synthesis of chiral amines, to improve the substrate scope of available enzymes and further even to alter the stereopreference of the enzymes [66]. In this section, we will discuss the recent advances in the protein engineering aspects of transaminase-mediated biocatalysis for the synthesis of chiral amines drugs and drug intermediates.

The knowledge obtained from the structure of various $\omega$-TAs has established that, generally, the active form of $\omega$-TA is a homodimer, and the active site is positioned at the interface of the monomers, wherein each monomer participates in the active site [67]. The substrate binding region of $\omega$-TAs is composed of two pockets: a large pocket that allows accommodation of substituents with rather broad size distribution, such as small alkyl to naphthyl groups and small binding pocket allows access to the small substituents, not exceeding that of a methyl group $[48,68]$. Although this characteristic architecture of the active site limits the substrate scope, it also contributes to the high stereopreference of $\omega$-TAs [69]. Until very recently, the number of $(R)$-selective $\omega$-TAs was very limited and much of the effort has been directed towards protein engineering approaches for the generation of stereospecific $\omega$-TAs, and to broaden their substrate scope. The first successful industrially applicable protein engineering approach was the development of the (R)-selective $\omega$-TA-117 from Arthrobacter sp. for the synthesis of the antidiabetic drug Sitagliptin [29]. The substrate ketone, pro-sitagliptin, is not a natural substrate and could not be accepted by wild-type enzyme. Extensive computational modeling, along with a directed evolution approach, was utilized to incorporate 27 mutations, not only in the active site of the enzyme but also in the interface of the enzyme dimer. This active variant was used at the pilot-scale production of Sitagliptin, wherein $92 \%$ yield with excellent enantioselectivity $(>99.95 \% e e)$ was afforded by $6 \mathrm{gL}^{-1}$ enzyme load. This improved process resulted in the reduction of total waste produced by $19 \%$, which was acknowledged by its achievement of the 'Presidential Green Chemistry Challenge Award for Greener Reaction Conditions' in 2010 [70].

Since the successful engineering of $\omega$-TA-117, many research groups have directed their scientific efforts to the engineering of active site pockets for the acceptance of bulkier substrates by TAs. For instance, the work by Midelfort et al. was directed towards making TAs amenable biocatalysts for synthesis of $\beta$-aminoesters from the corresponding $\beta$-ketoesters. The $(S)-\omega$-TAVf was engineered for the synthesis of $(3 S, 5 R)$-ethyl 3-amino-5-methyloctanoate; a key intermediate in the synthesis of imagabalin, a drug candidate in Phase III clinical trials for the treatment of generalized anxiety disorder. The final improved variant, $\mathrm{r} 414$, contained eight mutations (F19W/W57F/F85A/R88K/V153A/K163F/I259V/R415F), which displayed a 60-fold increase in initial reaction velocity for the transamination of $(R)$-ethyl 5-methyl 3-oxooctanoateto (3S,5R)-ethyl 3-amino-5-methyloctanoate (Figure 5) [71]. 


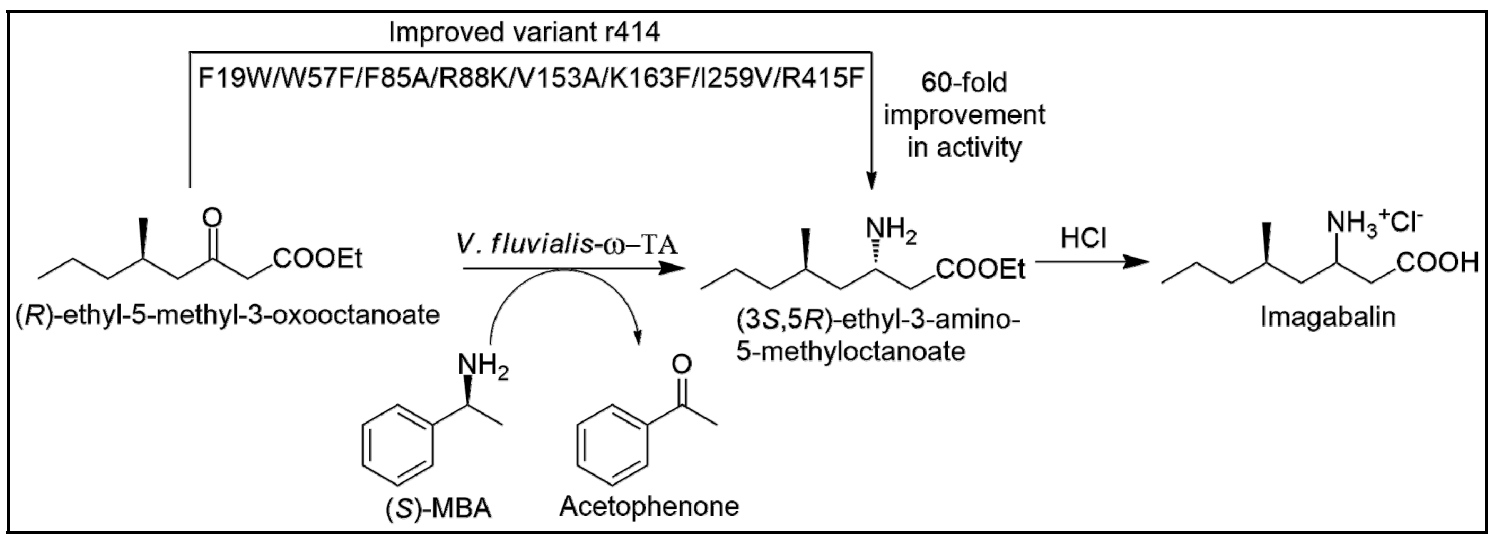

Figure 5. Improved production of Imagablin by protein engineering of (S)- $\omega$-TAVf [71]. (Reaction conditions: $4.0 \mathrm{~g}$ of wet $E$. coli cells containing $(S)$ - $\omega$-TAVf mutant $\mathrm{r} 414,88 \mathrm{~mL}$ potassium phosphate buffer (0.1 M, pH 7.0); $54 \mathrm{mg}$ pyridoxal phosphate; $1 \mathrm{~g}$ substrate, $7.5 \mathrm{~mL}$ of $1 \mathrm{M}$ solution of (S)- $\alpha$-MBA, $\left.30{ }^{\circ} \mathrm{C}, 24 \mathrm{~h}\right)$.

Further efforts to improve the substrate scope of (S)- $\omega$-TAVf to accommodate the bulky branched-chain substrates were carried out by Bornscheuer et al. [72]. In these studies, the most suitable mutation sites and amino acid substitutions were identified by bioinformatic analysis using 3DM. The volume of the substrate binding pocket was enlarged by the creation of a library that included mainly hydrophobic residues in the active site. The best variant containing four mutations (L56V, W57C, F85V, V153A) was able to catalyze the asymmetric synthesis of sterically demanding branched-chain chiral amines, which afforded complete conversion of the ketone and yielded the corresponding amine with $>99 \%$ ee, notably with a preference for the $(R)$-enantiomer.

In another study, $(S)-\omega-T A V f$ was engineered using a rational design strategy combining in silico and in vitro studies for the asymmetric synthesis of (S)-1-(1,1'-biphenyl-2-yl)ethanamine by $\omega$-TA-mediated transamination between bulky aromatic ketone substrate 2-acetylbiphenyl and the amine donor isopropylamine [73]. The incorporation of two mutations (W57G/R415A) generated a mutant that showed detectable enzyme activity, and the rationally designed variant (W57F/R88H/V153S/K163F/I259M/R415A/V422A) improved the reaction rate by >1716-fold towards the bulky ketone 2-acetylbiphenyl, producing the corresponding $(S)$-amine with excellent enantiomeric purity $(>99 \%$ ee).

Since the substrate specificity of $\omega$-TAs is largely controlled by steric constraints in the substrate-binding pockets, bulky $\alpha$-keto acids carrying a side chain bigger than an ethyl substituent generally are not accepted by $\omega$-TAs. The (S)-selective $\omega$-TA from Ochrobactrum anthropic ((S)- $\omega$-TAOa) was engineered by employing alanine scanning mutagenesis to reduce steric constraints and thereby to allow the small pocket to readily accept bulky substituents. Alanine substitution at residue L57 (L57A), a residue located in the large pocket, induces an altered binding orientation of a carboxyl group of keto acids and amino acids and thus was able to provide more room for the small pocket. This variant allowed the acceptance of bulkier substrates, 2-oxopentanoic acid, and L-norvaline and improved the activity towards these substrates by 48 -and 56 -fold, respectively. The applicability of the generated mutant was evaluated for the kinetic resolution of racemic norvaline and furthermore to produce optically pure L- and D-norvaline by asymmetric amination of 2-oxopentanoic acid [74]. In another study, Nobili et al. carried out systematic mutagenesis study of the active site residues of (S)- $\omega$-TAVf to expand its substrate scope towards two bulky ketones. This group identified two active mutants, F85L/V153A and Y150F/V153A, which showed a 30-fold increased activity in the conversion of (S)-phenylbutylamine and (R)-phenylglycinol, respectively [68]. However, saturation mutagenesis at the respective position in (S)- $\omega$-TAVf did not improve the activity towards the same substrates 
studied in the previous studies, implying that the substrate specificity of $\omega$-TA is a complex episode and cannot be directly related from one enzyme template to another.

In a contribution to expand the substrate scope of $\omega$-TAs, Pavlidis et al. [75] mutated a fold class I (S)- $\omega$-TA from Ruegeria sp. TM1040 [(S)- $\omega$-TARu; PDB ID: 3FCR] by rational design and identified an active variant with just four mutations (3FCR_QM; Y59W/Y87F/Y152F/T231A), which proved sufficient for the acceptance of bulkier ketones and enabled asymmetric synthesis of a wide set of bulky chiral amines on a preparative scale with excellent conversion, isolated yield and stereoselectivity. This group further carried out mutational studies on (S)- $\omega$-TAR $u$ for the synthesis of a bridged bicyclic amine exo-3-amino-8-aza-bicyclo[3.2.1]oct-8-yl-phenyl-methanone, a motif constituent of many neuroactive agents, from its corresponding ketone substrate [76]. Two active variants were identified (3FCR_QM/I234F) and (3FCR_QM/I234M), which exhibited specific activity of 80 and $116 \mathrm{mU} \mathrm{mg}^{-1}$, respectively, while maintaining absolute stereoselectivity compared to $45 \mathrm{mU} \mathrm{mg}^{-1}$ of the mutant identified in the previous studies (3FCR_QM) for the kinetic resolution of a bicyclic amine exo-3-amino-8-aza-bicyclo[3.2.1]oct-8-yl-phenyl-methanone.

Although (S)- $\omega$-TAR $u$ has successfully been engineered to accept aromatic (such as bicyclic) and thus planar bulky amines, the variants active towards the substrates carrying a bulky tert-butyl substituent adjacent to the carbonyl function, such as 2,2-dimethyl-1-phenyl-propan-1-one, were unavailable until very recently. To address this issue, $(S)-\omega$-TAR $u$ was engineered by introducing five mutations [Y59W/Y87L/T231A/L382M/G429A] [77]. This active variant enabled the asymmetric synthesis of (R)-2,2-dimethyl-1-phenylpropan-1-amine from the corresponding ketone substrate 2,2-dimethyl-1-phenyl-propan-1-one and isopropylamine as an amine donor. These studies suggested the critical importance of amino residue Y87, as it blocks the entrance for the sterically demanding tert-butyl moiety, and the introduction of a mutation at this position (Y87L) allowed the hydrophobic interaction between the substrate moiety and amino acid residue at position 87 , thus leading to the accommodation of the bulky substrate [77].

Protein engineering approaches have played a crucial role in the generation of highly efficient $\omega$-TAs. Various approaches, such as directed evolution and rationally designed engineering of $\omega$-TAs, not only improved the scope for bulkier substrates but also improved their enantioselectivity. Knowledge of the various putative sequences of protein families has successfully been used for the identification of novel transaminases. Various approaches have been utilized for improvement in kinetic resolution and asymmetric synthesis approaches. The removal of co-products by physical extraction using membrane bioreactors has been successfully implemented to favor the reaction equilibrium towards product formation. Furthermore, reaction engineering by employing cascade reactions to remove and/or recycle the product have also found a useful role in equilibrium shift. To this end, various 'smart' amine donors have been developed that allow the cyclization or the tautomerization. Ever since the successful demonstration of protein engineering for the industrial production of sitagliptin, various approaches of protein engineering have spurred improvement in the substrate scope of TAs and their enantioselectivities. 


\section{Establishing Stable $\omega$-TA Biocatalysts for Synthetic Applications}

The synthetic applicability of TA biocatalysts can be successfully extended to industrial scale only with the use of robust and reusable biocatalysts, which can offer excellent stability in non-physiological conditions. The stability of any enzymatic preparation can be exemplified as its thermodynamic stability (conformational stability of the enzyme structure), kinetic stability (stability over time) and operational stability, which includes thermostability and stability in organic solvents [78,79]. The following sections summarize the various strategies adopted to improve the stability of $\omega$-TAs and thereby their applicability in the synthesis of chiral amines.

\subsection{Finding Thermostable $\omega$-TAs}

Owing to their excellent stability, thermostable enzymes permit execution of the biocatalytic reaction at higher temperatures. This results in the achievement of higher reaction rates and furthermore to the easier removal of volatile by-products, thereby helping to shift the equilibrium of the reaction towards product formation [11,41]. Enzymes originating from thermophilic microorganisms naturally possess desired properties of high operational and thermodynamic stabilities [80]. Recently, Cerioli and co-workers [81] identified a $\omega$-TA from the halophilic bacterium Halomonas elongata exhibiting highest activity at $50{ }^{\circ} \mathrm{C}$. In addition, the enzyme activity was retained in the presence of co-solvents up-to $20 \%$, proving the enzyme suitable for industrial application of transamination of poorly water-soluble substrates. Chen et al. [82] improved the operational stability of $\omega$-TA from Chromobacterium violaceum ( $\omega$-TACv) by the addition of additives, co-solvents, and organic solvents, and demonstrated the first successful application of $\omega$-TA co-immobilized with surfactants. It was shown that the enzyme retains its active dimeric structure when it is stored in 50\% glycerol, $20 \%$ methanol or $10 \%$ DMSO. Mathew et al. recently identified two thermostable $\omega$-TAs, each from Thermomicrobium roseum ( $\omega$-TATr) and Sphaerobacter therlmophilus ( $\omega$-TASt) respectively $[33,83]$. A (S)- $\omega$-TATr showed improvement in residual activity when the enzyme was incubated for $1 \mathrm{~h}$ at 60 and $70{ }^{\circ} \mathrm{C}$, which was attributed to the refolding of an enzyme to its natural conformation at higher temperatures. In addition, this enzyme exhibited a broad substrate scope and could be utilized for the synthesis of chiral amines using asymmetric synthesis and kinetic resolution approaches [83]. Another thermostable TA, (S)- $\omega$-TASt, showed the highest activity at $60{ }^{\circ} \mathrm{C}$ and no loss of activity following $1 \mathrm{~h}$ incubation at this temperature was noticed. It was also reported that the stability of (S)- $\omega$-TAS was not adversely affected in the presence of $20 \%$ DMSO, implying the industrial potential of the enzyme [33]. More recently, Chen et al. [84] identified a thermostable $\omega$-TA from Geobacillus thermodenitrificans ( $\omega$-TAGt), which showed highest activity at $65^{\circ} \mathrm{C}$. The $\omega$-TAGt also exhibited 2.5-fold increase in activity when the enzyme was incubated for $8 \mathrm{~h}$ at $50{ }^{\circ} \mathrm{C}$ or $30 \mathrm{~min}$ at $60{ }^{\circ} \mathrm{C}$. Most recently, Ferrandi et al. [85] discovered the novel thermostable $\omega$-TA by exploiting the metagenomics approach. One of the three discovered $\omega$-TAs, B3-TA, was exceptionally thermostable and retained $85 \%$ and $40 \%$ of the initial activity after the incubation at $80^{\circ} \mathrm{C}$ for 5 days and 2 weeks, respectively. B3-TA is the most thermostable natural $\omega$-TA known till date, which also showed excellent tolerance toward different water-miscible and water immiscible organic solvents (Table 1). 
Table 1. Selected examples of recently discovered thermostable $\omega$-TAs.

\begin{tabular}{|c|c|c|c|c|c|c|}
\hline Sr. No. & Source & Enzyme Selectivity & Strategy Used & $\begin{array}{c}\text { Optimum } \\
\text { Temperature }\left({ }^{\circ} \mathrm{C}\right)\end{array}$ & Remarks & Reference \\
\hline 1 & $\begin{array}{l}\text { Halomonas elongata } \\
\text { DSM } 2581\end{array}$ & (S)-selective & $\begin{array}{l}\text { Conserved domain } \\
\text { analysis }\end{array}$ & 50 & $\begin{array}{l}\text { First study reported on } \omega \text {-TA from } \\
\text { the moderate halophile bacterium } \\
\text { H. elongate. The stability was } \\
\text { unaffected in the presence of } \\
\text { organic solvents. }\end{array}$ & [81] \\
\hline 2 & Chromobacterium violaceum & $(S)$-selective & & 65 & $\begin{array}{l}\text { The enzyme performance was } \\
\text { improved } 5 \text {-fold by a } \\
\text { co-lyophilization with surfactants }\end{array}$ & [82] \\
\hline 3 & Sphaerobacter thermophilus & (S)-selective & $\begin{array}{l}\text { BLAST search against } \\
\text { protein sequences } \\
\text { from thermophiles }\end{array}$ & 60 & $\begin{array}{l}\text { The enzyme was utilized for the } \\
\text { stereoselective synthesis of } \beta \text { - and } \\
\gamma \text {-amino acids }\end{array}$ & [33] \\
\hline 4 & Thermomicrobium roseum & $(S)$-selective & $\begin{array}{l}\text { BLAST search against } \\
\text { protein sequences } \\
\text { from thermophiles }\end{array}$ & 87 & $\begin{array}{l}\text { Volatile inhibitory byproducts } \\
\text { were removed by performing } \\
\text { asymmetric synthesis and kinetic } \\
\text { resolution at high temperature }\end{array}$ & [83] \\
\hline 5 & Geobacillus thermodenitrificans & $(S)$-selective & $\begin{array}{l}\text { BLAST search against } \\
\text { protein sequences } \\
\text { from thermophiles }\end{array}$ & 65 & $\begin{array}{l}\text { The enzyme showed relatively } \\
\text { good activity toward ketoses, } \\
\text { suggesting its potential for } \\
\text { catalyzing the asymmetric } \\
\text { synthesis of chiral amino alcohols. }\end{array}$ & [84] \\
\hline 6 & Hot spring metagenomes & $(S)$-selective & Metagenomics & 88 & $\begin{array}{l}\text { The most thermostable natural } \\
\omega \text {-TA known till date. }\end{array}$ & {$[85]$} \\
\hline
\end{tabular}




\subsection{Protein Engineering}

In addition to its application to the improvement of the substrate scope of $\omega$-TAs, protein engineering approaches have also been extended to improve the operational stability of the enzymes (Table 2). For instance, $(R)$-selective $\omega$-TA-117 from Arthrobacter sp., employed in the industrial production of sitagliptin, was engineered to improve its tolerance towards organic solvents [29]. Eleven rounds of evolution generated the optimized biocatalyst, which could afford a successful transamination of high substrate load $\left(50 \mathrm{~g} \mathrm{~L}^{-1}\right.$ pro-sitagliptin ketone) at $45{ }^{\circ} \mathrm{C}$, importantly, in the presence of $50 \%$ DMSO as a co-solvent. Pannuri et al. also engineered $\omega$-TAAc to improve its thermostability and subsequently used it for stereoselective synthesis of chiral amines [86].

The recent structural studies of $\omega$-TAs have established the fact that the homotetrameric conformations of $\omega$-TAs possess superior operational stability compared to their homodimeric counterparts $[87,88]$. It has also been postulated that the structural integrity of the cofactor-ring binding domain is a decisive factor in the operational stability of $\omega$-TAs. The cofactor-ring motif, positioned at the interface of monomer and dimer interface, is known to shape the bottom of the active site and to shield the cofactor from the solvent environment. To gain deeper insights into the role of cofactor-ring motif in the operational stability of tetrameric $\omega$-TAs, Börner et al. [89] recently generated several mutant libraries by targeting 32 amino acid residues around the active site and cofactor-ring domains. A double mutant (Asn161Ile and Tyr164Leu) increased the resting stability of the enzyme by $11^{\circ} \mathrm{C}$ compared to its wild-type parent enzyme. Notably, mutations introduced at these two positions conferred an excellent operational stability in biphasic reaction system at $45^{\circ} \mathrm{C}$. Moreover, the addition of third mutation (Gly51Ser) granted an additive effect in terms of thermal resistance and improved the thermal resistance of the resting state by $4{ }^{\circ} \mathrm{C}$ [89].

In another study, the $(R)$ - $\omega$-TA from Aspergillus terreus [(R)- $\omega$-TAAt] was recently engineered by employing the combination of an in silico strategy and mutational studies by site-directed mutagenesis [90]. The potential mutation sites were selected based on the folding energy calculations and four stabilized mutants (T130M, T130F, E133F and D134L) were obtained. These studies were successful in generating a single mutant (T130M) and double mutant (T130M/E133F), which improved the half-life $\left(\mathrm{t}_{1 / 2}\right)$ at $40{ }^{\circ} \mathrm{C}$ by $\sim 2.2$ and 3.3-fold, respectively. The mutations carried out at these positions generated new hydrophobic clusters and increased the hydrogen bonds, thereby improving the thermostability of the mutants compared to the wild-type protein.

Protein engineering by incorporation of noncanonical amino acids has also been proven to be an attractive strategy to improve the stability and activity of $\omega$-TAs [91]. Recently, Yun's group successfully used this approach for the improvement of enzymatic properties and thereby its synthetic applications of (S)- $w$-TAVf. The global incorporation of 3-fluorotyrosine resulted in 2.3-fold improvement of a half-life of engineered enzyme compared to its wild-type counterpart. Furthermore, the engineered (S)- $\omega$-TAVf could completely convert $25 \mathrm{mM}$ of acetophenone into (S)-MBA with excellent enantioselectivity $(e e>99 \%$ ) in the presence of $20 \%$ DMSO $(v / v)$, which was $\sim 2$-fold higher than wild-type $\omega$-TA $V f$ [92]. 
Table 2. Selected examples of application of protein engineering techniques to improve operational stability of $\omega$-TAs.

\begin{tabular}{|c|c|c|c|c|c|}
\hline Sr. No. & Source & Enzyme Selectivity & Strategy Used & Remarks & Reference \\
\hline 1 & Arthrobacter sp. & $(R)$-selective & $\begin{array}{l}\text { Substrate walking, modeling, } \\
\text { and mutation approach }\end{array}$ & $\begin{array}{l}11 \text { rounds of evolution generated the } \\
\text { optimized biocatalyst, which could afford a } \\
\text { successful transamination of in the presence } \\
\text { of } 50 \% \text { DMSO as a co-solvent }\end{array}$ & [29] \\
\hline 2 & Arthobacter citreus & $(S)$-selective & $\begin{array}{l}\text { Structure-guided } \\
\text { enzyme mutagenesis }\end{array}$ & $\begin{array}{l}\text { The enzyme was used for the industrial } \\
\text { production of substituted aminotetraline }\end{array}$ & [86] \\
\hline 3 & $\begin{array}{c}\text { Novel enzyme from } \\
\text { c-LEcta'smetagenomic library }\end{array}$ & & Semi-rational mutagenesis & $\begin{array}{l}32 \text { amino acid residues were targeted around } \\
\text { the active site including the cofactor-ring } \\
\text { motif for superior operational, thermo- and } \\
\text { solvent stability }\end{array}$ & [89] \\
\hline 4 & Aspergillus terreus & $(R)$-selective & $\begin{array}{l}\text { In silico design employing } \\
\text { B-factor and folding free } \\
\text { energy calculations }\end{array}$ & $\begin{array}{l}\text { The optimum catalytic temperature of a } \\
\text { mutant } \mathrm{T} 130 \mathrm{~F} \text { was increased by } 10^{\circ} \mathrm{C}\end{array}$ & [90] \\
\hline 5 & Sphaerobacter thermophilus & $(S)$-selective & $\begin{array}{l}\text { Residue-specific andsite-specific } \\
\text { incorporation of unnatural } \\
\text { amino acids }\end{array}$ & $\begin{array}{l}\text { The residue-specific incorporation showed } \\
2 \text {-fold enhancement in the half life at } 70{ }^{\circ} \mathrm{C}\end{array}$ & [91] \\
\hline 6 & Vibrio fluvialis JS17 & $(S)$-selective & $\begin{array}{l}\text { Global incorporation of } \\
\text { unnatural amino acids }\end{array}$ & $\begin{array}{l}\text { Mutant exhibited } \sim 2 \text {-fold higher tolerance } \\
\text { towards } 20 \% \text { DMSO compared to wild-type }\end{array}$ & [92] \\
\hline
\end{tabular}




\subsection{Enzyme Immobilization}

A single enzyme can differentially perform in different formulations in terms of activity and stability. Although the cell-free, purified form of a protein is the most desirable form of any biocatalysts, the higher purification costs limit its application on large scales. Biocatalyst in another form i.e., cell free extracts, can also be used if the target protein is sufficiently overexpressed. However, the long-term storage stability of the purified as well as cell free extracts is poor [12]. Therefore, use of the whole cells expressing the biocatalyst of interest is of potential use. However, the major limitation of the use of whole cell biocatalysts is the poor accessibility of the substrate to the enzymes located within the cells [93].

One potential approach to improve the stability of biocatalysts is their immobilization. Immobilization is advantageous owing to its low downstream requirements, as it allows the easy recovery of the biocatalysts and their reuse in the subsequent batch or continuous reactions $[42,93,94]$. Immobilization has been widely used to improve the operational and storage stability of $\omega$-TAs (Table 3). For instance, Koszelewski et al. [95] encapsulated the commercially available enzymes TA-117, TA-113, TA-114 and $\omega$-TAVf using sol-gel/celite matrix for the first time. The immobilized TA-117 exhibited excellent operational stability and retained about $78 \%$ of the initial activity after eight repetitive uses, most importantly, without compromising the enantioselectivity. The immobilization by covalent attachment using various support materials such as chitosan is also widely reported [96-99]. De Souza et al. [100] recently utilized cellulose for immobilization of $\omega$-TAVf. The $\omega$-TA $V f$ immobilized in the epoxy-functionalized cellulose conferred excellent temperature stability and reusability, wherein enzyme was consistently active over the broad range of temperature from 30 to $60{ }^{\circ} \mathrm{C}$ and for four repetitive cycles in the asymmetric synthesis of (S)-phenylethylamine.

The entrapment of whole cells expressing $\omega$-TAs using natural materials such as Ca-alginate, gelatin, or agarose has been reported. For instance, Rehn et al. compared the various methods of immobilization of recombinant $E$. coli cells expressing $\omega$-TAAc. Chitosan proved to be the method of choice for the whole-cell immobilization as it retained $>90 \%$ activity after eight successive batches [42]. In another study, Cardenas-Fernandez et al. successfully overcame the diffusional limitations of whole-cell immobilization by entrapping the permeabilized whole cells in PVA-gel (Lentikats ${ }^{\circledR}$ ) [101].

While most of the non-commercial supports limit their application because of the labor-intensive preparations prior to immobilization, commercially available ready-to-use supports such as polymeric resins are feasible. Neto et al. [41] recently immobilized (S)- $\omega$-TA (ATA-47) and (R)- $\omega$-TA (Ate-TA) using commercially available polemeric resins as enzyme carriers. Among six, two enzyme carriers i.e., (Relizyme HA403; pore size-40-60 nm and Supabeads EC-HA; pore size-10-20 nm; both having hexamethylamino functional groups) allowed the reuse of the preparation for $250 \mathrm{~h}$ of operation with retention of more than $50 \%$ of the initial activity. In addition, the immobilized preparations increased thermal stability, allowing storing the enzyme for more than 60 days at room temperature [41]. Most recently, Abaházi et al. [1] covalently immobilized Try60Cys mutant of $\omega$-TACv on bisepoxide-activated polymeric resins. The enzyme mutant immobilized by linking it to polymeric resin with ethylamine function activated with glycerol diglycidyl ether-EA-G could preserve the activity even in the high concentration of DMSO $(50 \% \mathrm{v} / \mathrm{v})$. Furthermore, this enzyme preparation could be used for 19 consecutive cycles in batch mode for the kinetic resolution of rac-4-phenylbutan-2-amine to its corresponding $R$-enantiomer, a precursor for antihypertensive dilevalol, with excellent activity and selectivity $(C \sim 50 \%, e e>99 \%)$.

Protein fusion tags, such as polyhistidine tags, provide an efficient protein purification by affinity chromatography and allow the enzyme immobilization in assembling immobilized enzyme microreactors (IEMR) [11,102,103]. IEMRs are the unique platforms for in vitro multi-enzymatic synthetic pathways. Furthermore, recent advances in nanotechnology have provided several nanomaterials for the efficient immobilization of the enzymes. Nanomaterials provide the large surface area that improves the adsorption of proteins and thereby allow the separation of protein in a low-concentration samples [104] Immobilization of $\omega$-TAs using $\mathrm{Ni}^{2+}$-chelated polydopamine magnetic nanoparticles [104], magnetic $\mathrm{PVA}-\mathrm{Fe}_{3} \mathrm{O}_{4}$ nanoparticles [105] and $\mathrm{MnO}_{2}$ nanorods [106] has been recently reported in the literature. 
Table 3. Selected examples of immobilization techniques used to improve the operational stability of $\omega$-TAs.

\begin{tabular}{|c|c|c|c|c|c|}
\hline Sr. No. & Source & Type of Immobilization & $\begin{array}{l}\text { Support Used for } \\
\text { Immobilization }\end{array}$ & Comment & Reference \\
\hline 1 & $\begin{array}{l}\text { Chromobacterium violaceum } \\
\quad \text { (Trp60Cys mutant) }\end{array}$ & Covalent binding & $\begin{array}{l}\text { bisepoxide-activated } \\
\text { polymeric resins }\end{array}$ & $\begin{array}{l}\text { Immobilized preparation was used for } 19 \text { consecutive } \\
\text { reaction cycles and in media containing up to } 50 \%(v / v) \\
\text { DMSO as co-solvent in batch mode reactions. }\end{array}$ & [1] \\
\hline 2 & (S)-selective ATA-47 & Ionic interaction & $\begin{array}{c}\text { Relizyme HA403 } \\
\text { (commercial material) }\end{array}$ & $\begin{array}{l}\text { Immobilized preparation retained more than } 50 \% \text { initial } \\
\text { activity for } 8 \text { cycles (each of } 24 \mathrm{~h} \text {; corresponding to more than } \\
250 \mathrm{~h} \text { of operation) }\end{array}$ & [41] \\
\hline 3 & (R)-selective Ate-TA & Hydrophobic & $\begin{array}{l}\text { Supabeads EC-HA } \\
\text { (commercial material) }\end{array}$ & $\begin{array}{l}\text { The immobilized preparation increased the thermal stability, } \\
\text { allowing storing the enzyme for more than } 60 \text { days }\end{array}$ & [41] \\
\hline 4 & $\omega-T A 117$ & Sol-gel entrapment & Celite 545 & $\begin{array}{l}\text { The immobilized enzyme preparation could be recycledeight } \\
\text { times with only moderate decrease of activity for each cycle }\end{array}$ & [95] \\
\hline 5 & Gibberella zeae & Covalent binding & Modified chitosan & Significant improvement in $\mathrm{pH}$ and temperature stability & [96] \\
\hline 6 & Neosartorya fischeri & Covalent binding & Modified chitosan & Significant improvement in $\mathrm{pH}$ and temperature stability & [96] \\
\hline 7 & Aspergillus fumigatus & Covalent binding & Chitosan & $\begin{array}{l}\text { The immobilized enzyme showed higher activity at } 70^{\circ} \mathrm{C} \\
\text { compared to free enzyme }\end{array}$ & [97] \\
\hline 8 & Ruegeria pomeroyi & Covalent binding & Chitosan & The immobilized enzyme retained activity after four batches & [97] \\
\hline 9 & Vibrio fluvialis JS17 & Covalent binding & Chitosan & $\begin{array}{l}\text { Significant improvement in stability over broad range of } \mathrm{pH} \\
\text { and temperature }\end{array}$ & [99] \\
\hline 10 & Vibrio fluvialis & Covalent binding & Functionalized cellulose & The immobilized enzyme retained activity for four cycles & [100] \\
\hline 11 & Bradyrhizobium japonicum & Affinity & $\begin{array}{l}\mathrm{Ni}^{2+} \text {-functionalized } \\
\text { polydopamine } \\
\text { magneticna noparticles }\end{array}$ & $\begin{array}{l}\text { Simultaneous purification and immobilization of the } \\
\text { his-tagged protein could be achieved }\end{array}$ & [104] \\
\hline 12 & Mycobacterium vanbaalenii & Covalent binding & $\begin{array}{l}\text { magnetic } \mathrm{PVA}-\mathrm{Fe}_{3} \mathrm{O}_{4} \\
\text { nanoparticles }\end{array}$ & $\begin{array}{l}\text { The immobilized enzyme could be successfully reused for } \\
13 \text { times in biotransformation }\end{array}$ & [105] \\
\hline
\end{tabular}




\section{Cascade Reactions Involving $\omega$-TAs}

Enzymatic cascades, wherein several independent reactions proceed simultaneously, offer numerous advantages in the production of target compounds, such as shortened synthetic routes, minimization of the use of organic solvents, and improvement in atom efficiency [11,12]. Furthermore, the easier handling of unstable intermediates and the control of unfavorable reaction equilibrium are added benefits of using biocatalytic cascades [107-109]. Cascade reactions have been categorized into four main types: (1) Linear cascades represent consecutive transformations in one-pot. (2) Parallel cascades, which are frequently used in redox biocatalysis wherein the product formation is coupled with a simultaneously proceeding second reaction. (3) The third type, orthogonal cascades, are closely related to parallel cascades and are generally used to shift the reaction equilibrium towards product formation. (4) Cyclic cascades, which are generally used for the stereoinversion processes. Readers are referred to recent reviews [107-113], which have elegantly elaborated on the advancements achieved in the field of cascade reactions.

Multi-enzymatic cascades involving $\omega$-TAs have been successfully used for the amination of the hydroxyl functional groups of alcohols to their corresponding amines. For instance, Fuchs et al. [114] utilized the cascade of galactose oxidase and $\omega$-TAs for the amination of benzylic and cinnamic alcohols. In the first step, alcohol substrates are converted to their corresponding aldehydes in the presence of galactose oxidase. In the subsequent step, the transamination of aldehyde intermediates arecatalyzed by $\omega$-TAs (Figure 6).

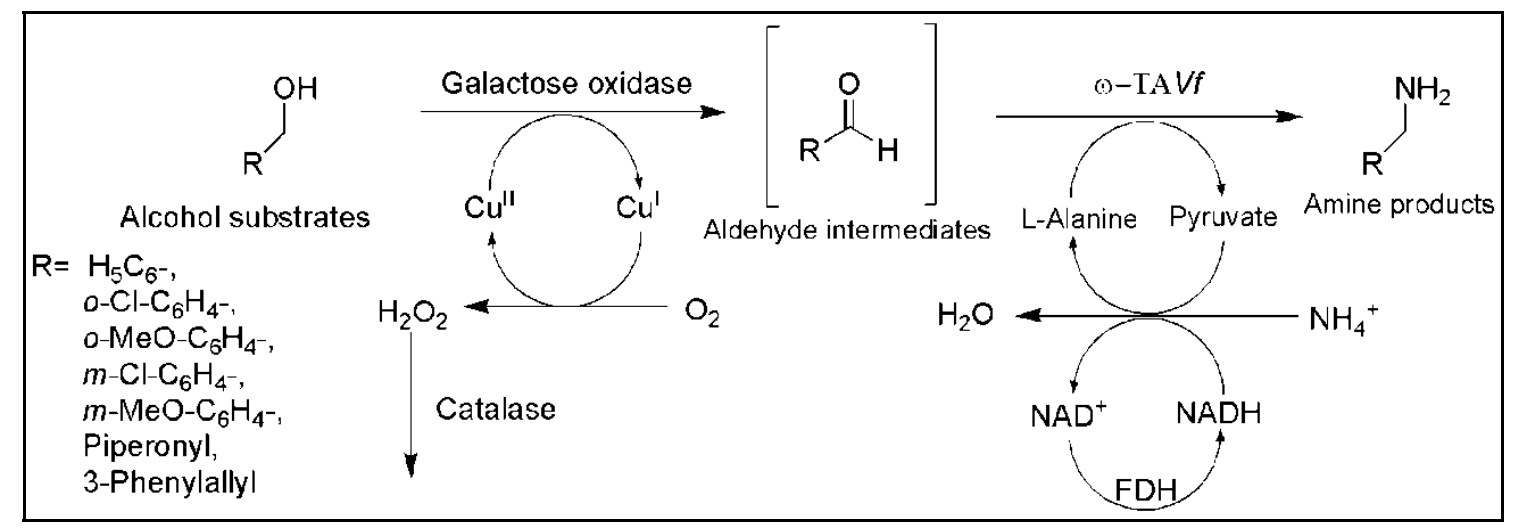

Figure 6. Biocatalytic cascade employing galactose oxidase and $\omega$-TA for the amination of benzylic/cinnamic alcohols (reprinted from [114], with permission of The Royal Society of Chemistry). (Reaction conditions: $50 \mathrm{mM}$ substrate, $20 \mathrm{mg}$ lyophilized E. coli BL21(DE3) cells over-expressing

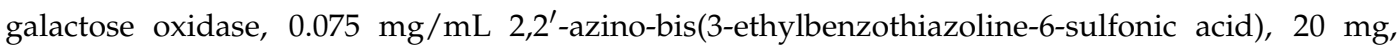
lyophilized E. coli BL21(DE3) cells over-expressing $\omega$-TAVf, Sodium phosphate buffer (100 mM, $\mathrm{pH}$ 7.0), $1 \mathrm{mM}$ PLP, $10 \mathrm{mM} \mathrm{CuSO}_{4}, 7.5 \mathrm{mg}$ alanine dehydrogenase, 20 U glucose dehydrogenase, $150 \mathrm{mM}$ L-alanine, $120 \mathrm{mM}$ (2.4 equiv) glucose, R.T., $24 \mathrm{~h}$ ).

Similarly, an artificial redox-neutral cascade, employing alcohol dehydrogenase, alanine dehydrogenase, and $\omega$-TA, has been recently utilized for the conversion of ether alcohol substrates to their corresponding ether amine products [115]. Initially, alcohol ether substrates were converted to the corresponding aldehydes or ketones using ADH from G. stearothermophilus. $\omega$-TACv subsequently catalyzed the amination of these intermediates, wherein AlaDH from $V$. proteolyticus recycled pyruvate to L-alanine with the simultaneous regeneration of the $\mathrm{NAD}^{+}$cofactor (Figure 7). 


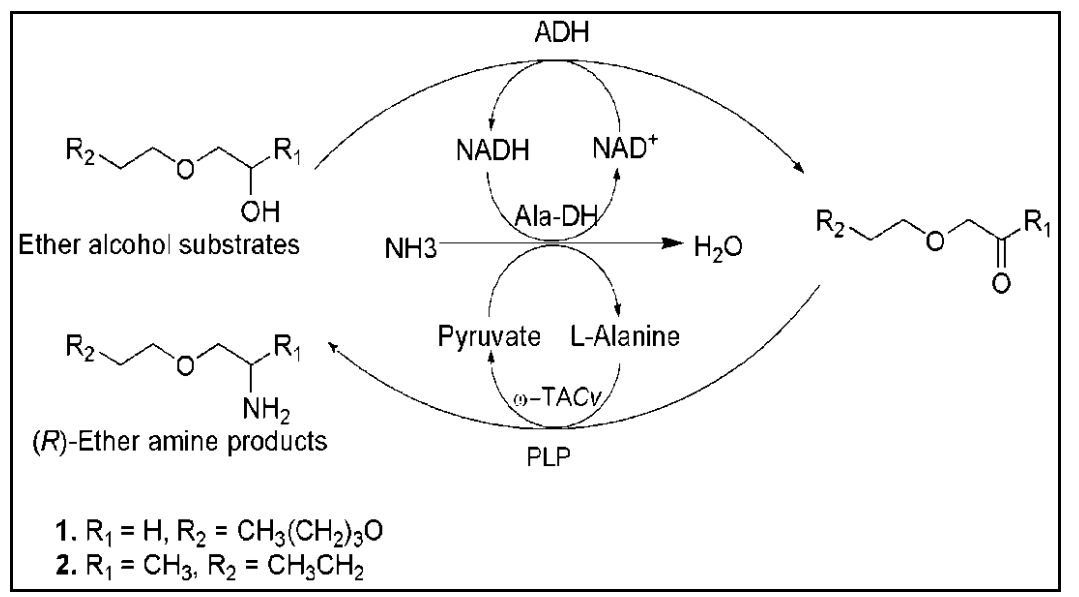

Figure 7. Artificial redox-neutral cascade employing alcohol dehydrogenase, $\omega$-TA and alanine dehydrogenase for the synthesis of ether amines from ether alcohol substrates (reprinted from [115] with the permission of John Wiley and Sons). (Reaction conditions: $10 \mathrm{mM}$ substrate, $280 \mathrm{mM}$ ammonia, ammonium carbamate buffer ( $40 \mathrm{mM}, \mathrm{pH} 9.0), 1 \mathrm{mM} \mathrm{NAD}^{+}, 0.35 \mathrm{mM} \mathrm{PLP}, 0.5 \mathrm{mM}$ L-Alanine, $0.1 \mathrm{mg} / \mathrm{mL}$ ADH, $0.004 \mathrm{mg} / \mathrm{mL}$ Ala-DH, $\left.0.064 \mathrm{mg} / \mathrm{mL} \omega-\mathrm{TACv}, 30{ }^{\circ} \mathrm{C}\right)$.

Chiral amino-alcohols are known as common constituents of many natural products, pharmaceuticals and chiral auxiliaries used in chemical syntheses [116]. For instance, a chiral amino-triol, (2S,3R)-2-amino-1,3,4-butanetriol (ABT), is used as a precursor for the synthesis of statins and ultimately for a HIV-protease inhibitor Nelfinavir. Gruber et al. [117] recently demonstrated a novel 2-step-enzymatic synthesis of approach, employing transketolase and $\omega$-TA, for the synthesis of $\mathrm{ABT}$ in a continuous-flow microreactor system. In the initial step, transketolase -catalyzed asymmetric carbon-carbon bond formation between hydroxypyruvate and glycoaldehyde led to the generation of L-Erythrulose. In the subsequent step, $\omega$-TA-catalyzed conversion of the keto-group into a chiral amino group generated ABT (Figure 8).

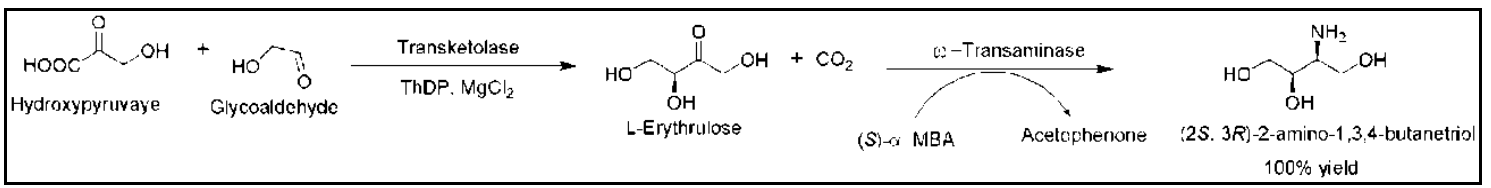

Figure 8. Biocatalytic cascade employing transketolase and $\omega$-TA for the synthesis of amino alcohol (2S,3R)-2-amino-1,3,4-butanetriol (Reprinted from [117], with the permission of John Wiley and Sons). (Reaction conditions: $50 \mathrm{mM}$ substrate, $3.25 \mathrm{U} / \mathrm{mL}$ transketolase, $4.8 \mathrm{mM}$ thiamine diphosphate (ThDP), $19.6 \mathrm{mM} \mathrm{MgCl}_{2}, 10 \mathrm{mM}(S)-\alpha-\mathrm{MBA}, 27 \mathrm{U} / \mathrm{mL} \omega$-TA, $2 \mathrm{mM}$ PLP, Tris-HCl buffer (100 mM, pH 9.0), R.T.).

Despite its complexity, sophisticated enzymatic cascades were recently developed for the synthesis of pharmaceutically important alkaloid scaffolds, such as THIQs. For instance, Erdmann et al. [118] recently reported the synthesis of 1,3,4-trisubstituted THIQs with three chiral centers by employing the cascade of three enzymes, namely carboligase, $\omega$-TACv and a mutant of Pictet-Spenglerase enzyme Norcoclaurine synthase (NCS) from Thalictrum flavum. In the first reaction, carboligase catalyzed the generation of (R)-1-hydroxy-1-(3-hydroxyphenyl)propan-2-one from 3-hydroxybenzaldehyde and pyruvate substrates. The transamination catalyzed by $\omega$-TACv generated the corresponding amino product from (R)-1-hydroxy-1-(3-hydroxyphenyl)propan-2-one. Subsequent Pictet-Spengler condensation, catalyzed by NCS-Tf, generated a THIQ product (1S,3S,4R)-1-benzyl-3-methyl-1,2,3,4-THIQ-4,6-diol (Figure 9). In addition, opposite stereoselectivities of the C1-substituted-THIQs could be achieved following the chemical cyclization by phosphate (Figure 9), providing access to both the orientations of the substituted THIQ [118]. 


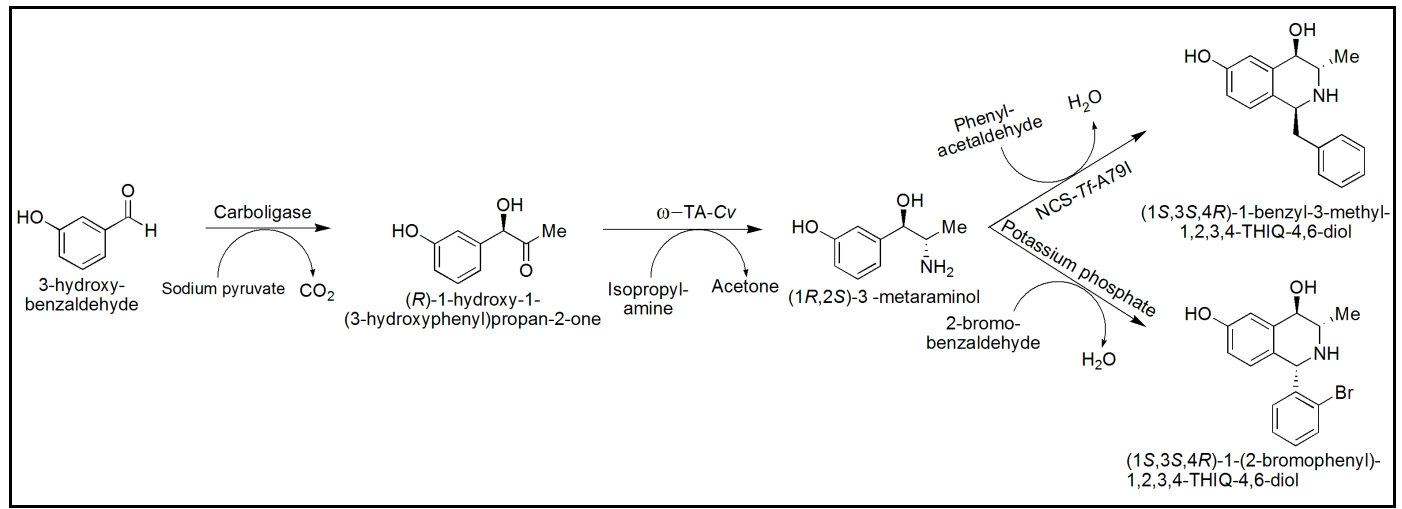

Figure 9. Enzymatic and Chemo-enzymatic synthesis of 1-benzyl-THIQs employing the cascade of carboligase, $\omega$-TA and NCS [118]. (Reaction conditions: step 1: $10 \mathrm{mM}$ substrate, HEPES buffer (100 mM, pH 7.5), $5 \mathrm{mM} \mathrm{MgCl}$, $0.1 \mathrm{mM}$ ThDP, $0.05 \mathrm{mM}$ FAD, $20 \mathrm{mM}$ sodium pyruvate, 2.5\% DMSO $(v / v), 0.5 \mathrm{mg} / \mathrm{mL}$ acetohydroxy acid synthase I from E. coli (EcAHAS-I), $30{ }^{\circ} \mathrm{C}, 750 \mathrm{rpm}$; Step 2: $0.2 \mathrm{mM}$ PLP, $100 \mathrm{mM}$ isopropylamine, 3.1\% DMSO $(v / v), 3 \mathrm{mg} / \mathrm{mL} \omega$-TACv, $30^{\circ} \mathrm{C}, 750 \mathrm{rpm}$; step 3 (Enzymatic): $9.5 \mathrm{~mm}$ phenylacetaldehyde, $2.5 \%$ DMSO $(v / v), 0.5 \mathrm{mg} / \mathrm{mL} \mathrm{NCS}-\mathrm{Tf}$-A79I), $37^{\circ} \mathrm{C}, 750 \mathrm{rpm}$; step 3 (Chemo-enzymatic): $10 \mathrm{mM}$ bromobenzaldehyde, $200 \mathrm{mM}$ potassium phosphate buffer, $\mathrm{pH} 7.0,50{ }^{\circ} \mathrm{C}$, $750 \mathrm{rpm})$.

Another Pictet-Spenglerase enzyme, Strictosidine synthase (STR), has also been employed in the cascade consisting of $\omega$-TAs for the synthesis of (S)-strictosidine derivatives possessing an additional stereogenic center at $\mathrm{C} 3$ of the tetrahydro- $\beta$-carboline moiety [119]. In the initial reaction, $\alpha$-methyltryptamine derivatives were generated using $\omega$-TA-catalyzed amination of prochiral ketone substrates. Subsequent STR-catalyzed condensation of $\alpha$-methyltryptamine derivatives with secologanin formed optically pure C3-methyl-substituted strictosidine derivatives. Furthermore, the use of stereocomplementary $\omega$-TAs allowed the synthesis of both the enantiomers of $\alpha$-methyltryptamine derivatives, which ultimately allowed the synthesis of both the epimers of C3-methyl-substituted strictosidine derivatives [119] (Figure 10).

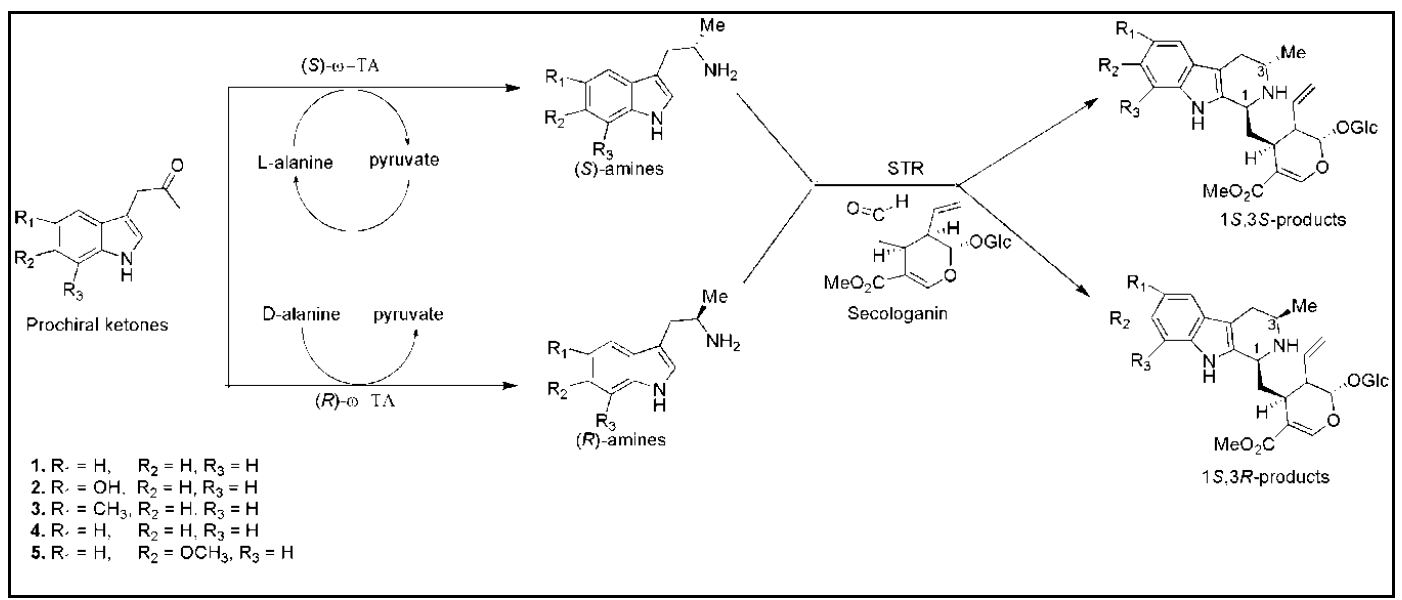

Figure 10. Biocatalytic cascade employing $\omega$-TA and STR for the chemo-enzymatic synthesis of C3-methyl-substituted enantiopure Strictosidine derivatives (adapted with permission from [119], Copyright (2015) American Chemical Society). (Reaction conditions: $2 \mathrm{mM}$ substrate, potassium phosphate buffer (100 mM, pH 7.0), 10 mg lyophilized E. coli cells over-expressing $\omega$-TA, 90 mU STR, $250 \mathrm{mM}$ D-or L-alanine, $150 \mathrm{mM}$ ammonium formate, $1 \mathrm{mM} \mathrm{PLP}, 1 \mathrm{mM} \mathrm{NAD}+11 \mathrm{U} \mathrm{FDH}, 4 \mathrm{U}$ Ala-DH, $\operatorname{DMSO}(5 \%, v / v), 4 \mathrm{mM}$ secologanin, $\left.24 \mathrm{~h}, 30^{\circ} \mathrm{C}\right)$. 


\section{Conclusions and Prospects}

The ever-increasing demands of enzyme-mediated synthesis of enantiopure amines are being elegantly met by engineered $\omega$-TAs. The decreasing costs of gene synthesis and the increasing availability of the genome sequences have given access to a new pool of potential $\omega$-TAs. Therefore, the exploitation of these novel biocatalysts can provide a massive addition to the application of biocatalysts for the industrial synthesis of various pharmaceuticals, fine chemicals, and other important industrial products. This accelerated rate of biocatalyst discovery has permitted scientific community to enter a 'golden age' of biocatalysis[120]. Despite this progress, many of the recently-discovered enzymes still display poor substrate tolerance profiles, making their role as routine catalysts unlikely. Nevertheless, the recent advances in the reaction engineering such as, development of 'smart' amine donors, in-situ product removal, and application of cascade reactions, have successfully addressed the major challenge of poor reaction equilibrium towards product formation. In addition, protein engineering strategies have played a pivotal role in expanding the substrate scope of recently discovered biocatalysts and further in improving the thermodynamic and operational stabilities of the already-available enzymes. The future of $\omega$-TA biocatalysis research should also see the discovery of novel enzymes, particularly thermostable ones, by utilizing metagenomic approaches. The application of engineered $\omega$-TAs for the industrial production of sitagliptin has already exhibited the synthetic potential of these potent biocatalysts. Engineered $\omega$-TAs will continue to develop as a competitive alternative technology to conventional syntheses for the production of enantiomerically enriched amines.

Author Contributions: M.D.P. researched the literature and drafted the manuscript; G.G., A.B. and H.Y. discussed ideas and edited the manuscript. All the authors revised and approved the manuscript.

Funding: This research was supported in part by Basic Science Research Program through the National Research Foundation of Korea (NRF) funded by the Ministry of Science, ICT and future Planning (2016R1A2B2014794).

Acknowledgments: M.D.P. gratefully acknowledges 'Foreign Research Professorship' under '2018-KU Brain Pool program' from Konkuk University, Seoul.

Conflicts of Interest: The authors declare no conflict of interest.

\section{References}

1. Abaházi, E.; Sátorhelyi, P.; Erdélyi, B.; Vértessy, B.G.; Land, H.; Paizs, C.; Berglund, P.; Poppe, L. Covalently immobilized Trp60Cys mutant of $\omega$-transaminase from Chromobacterium violaceum for kinetic resolution of racemic amines in batch and continuous-flow modes. Biochem. Eng. J. 2018, 132, 270-278. [CrossRef]

2. Zheng, G.W.; Xu, J.H. New opportunities for biocatalysis: Driving the synthesis of chiral chemicals. Curr. Opin. Biotechnol. 2011, 22, 784-792. [CrossRef] [PubMed]

3. Solano, D.M.; Hoyos, P.; Hernáiz, M.J.; Alcántara, A.R.; Sánchez-Montero, J.M. Industrial biotransformations in the synthesis of building blocks leading to enantiopure drugs. Bioresour. Technol. 2012, 115, $196-207$. [CrossRef] [PubMed]

4. Albarran-Velo, J.; Gonzalez-Martinez, D.; Gotor-Fernandez, V. Stereoselective biocatalysis: A mature technology for the asymmetric synthesis of pharmaceutical building blocks. Biocatal. Biotransform. 2018, 36, 102-130. [CrossRef]

5. Yang, G.; Ding, Y. Recent advances in biocatalyst discovery, development and applications. Bioorg. Med. Chem. 2014, 22, 5604-5612. [CrossRef] [PubMed]

6. Simon, R.C.; Mutti, F.G.; Kroutil, W. Biocatalytic synthesis of enantiopure building blocks for pharmaceuticals. Drug Discov. Today Technol. 2013, 10, e37-e44. [CrossRef] [PubMed]

7. Truppo, M.D. Biocatalysis in the Pharmaceutical Industry-The Need for Speed. ACS Med. Chem. Lett. 2017, 8, 476-480. [CrossRef] [PubMed]

8. Bornscheuer, U.T. The fourth wave of biocatalysis is approaching. Phil. Trans. R. Soc. A 2018, 376, 20170063. [CrossRef] [PubMed]

9. Ghislieri, D.; Turner, N.J. Biocatalytic Approaches to the Synthesis of Enantiomerically Pure Chiral Amines. Top. Catal. 2014, 57, 284-300. [CrossRef] 
10. Gomm, A.; O'Reilly, E. Transaminases for chiral amine synthesis. Curr. Opin. Chem. Biol. 2018, 43, $106-112$. [CrossRef] [PubMed]

11. Slabu, I.; Galman, J.L.; Lloyd, R.C.; Turner, N.J. Discovery, Engineering, and Synthetic Application of Transaminase Biocatalysts. ACS Catal. 2017, 7, 8263-8284. [CrossRef]

12. Guo, F.; Berglund, P. Transaminase biocatalysis: Optimization and application. Green Chem. 2017, 19, 333-360. [CrossRef]

13. Höhne, M.; Bornscheuer, U.T. Biocatalytic routes to optically active amines. Chem CatChem 2009, 1, 42-51. [CrossRef]

14. Koszelewski, D.; Tauber, K.; Faber, K.; Kroutil, W. $\omega$-Transaminases for the synthesis of non-racemic $\alpha$-chiral primary amines. Trends Biotechnol. 2010, 28, 324-332. [CrossRef] [PubMed]

15. Brundiek, H.; Höhne, M. Transaminases-A Biosynthetic Route for Chiral Amines. In Applied Biocatalysis: from Fundamental Science to Industrial Applications; Hilterhaus, L., Liese, A., Kettling, U., Antranikian, G., Eds.; Wiley-VCH Verlag GmbH \& Co. KGaA: Weinheim, Germany, 2016; pp. 199-218.

16. Ferrandi, E.E.; Monti, D. Amine transaminases in chiral amines synthesis: Recent advances and challenges. World J. Microbiol. Biotechnol. 2018, 34, 13. [CrossRef] [PubMed]

17. Busto, E.; Simon, R.C.; Richter, N.; Kroutil, W. Enzymatic Synthesis of Chiral Amines using $\omega$-Transaminases, Amine Oxidases, and the Berberine Bridge Enzyme. In Green Biocatalysis; Patel, R.N., Ed.; John Wiley \& Sons, Inc.: Hoboken, NJ, USA, 2016; pp. 17-57.

18. Mathew, S.; Yun, H. $\omega$-Transaminases for the production of optically pure amines and unnatural amino acids. ACS Catal. 2012, 2, 993-1001. [CrossRef]

19. Szmejda, K.; Florczak, T.; Jodłowska, I.; Turkiewicz, M. Extremophilic and modified aminotransferases as a versatile tool for the synthesis of optically pure building blocks for pharmaceutical industry. Biotechnol. Food Sci. 2017, 81, 23-34.

20. Kelly, S.A.; Pohle, S.; Wharry, S.; Mix, S.; Allen, C.C.; Moody, T.S.; Gilmore, B.F. Application of $\omega$-Transaminases in the Pharmaceutical Industry. Chem. Rev. 2018, 118, 349-367. [CrossRef] [PubMed]

21. Berglund, P.; Humble, M.S.; Branneby, C. Comprehensive Chirality; Carreira, E.M., Yamamoto, H., Eds.; Elsevier: Amsterdam, The Nertherland, 2012; Volume 7, pp. 390-401.

22. Kohls, H.; Steffen-Munsberg, F.; Höhne, M. Recent achievements in developing the biocatalytic toolbox for chiral amine synthesis. Curr. Opin. Chem. Biol. 2014, 19, 180-192. [CrossRef] [PubMed]

23. Matcham, G.W.; Stirling, D.I.; Zeitlin, A.L. Enantiomeric Enrichment and Stereoselective Synthesis of Chiral amines. U.S. Patent 4950606 A, 5 April 1994.

24. Wu, H.L.; Zhang, J.D.; Zhang, C.F.; Fan, X.J.; Chang, H.H.; Wei, W.L. Characterization of Four New Distinct $\omega$-Transaminases from Pseudomonas putida NBRC 14164 for Kinetic Resolution of Racemic Amines and Amino Alcohols. Appl. Biochem. Biotechnol. 2017, 181, 972-985. [CrossRef] [PubMed]

25. Höhne, M.; Robins, K.; Bornscheuer, U.T. A Protection Strategy Substantially Enhances Rate and Enantioselectivity in $\omega$-Transaminase-Catalyzed Kinetic Resolutions. Adv. Synth. Catal. 2008, 350, 807-812. [CrossRef]

26. Kaulmann, U.; Smithies, K.; Smith, M.E.; Hailes, H.C.; Ward, J.M. Substrate spectrum of $\omega$-transaminase from Chromobacterium violaceum DSM30191 and its potential for biocatalysis. Enzyme Microb. Technol. 2007, 41, 628-637. [CrossRef]

27. Hanson, R.L.; Davis, B.L.; Chen, Y.; Goldberg, S.L.; Parker, W.L.; Tully, T.P.; Montana, M.A.; Patel, R.N. Preparation of $(R)$-Amines from Racemic Amines with an (S)-Amine Transaminase from Bacillus megaterium. Adv. Synth. Catal. 2008, 350, 1367-1375. [CrossRef]

28. Malik, M.S.; Park, E.S.; Shin, J.S. $\omega$-Transaminase-catalyzed kinetic resolution of chiral amines using L-threonine as an amino acceptor precursor. Green Chem. 2012, 14, 2137-2140. [CrossRef]

29. Savile, C.K.; Janey, J.M.; Mundorff, E.C.; Moore, J.C.; Tam, S.; Jarvis, W.R.; Colbeck, J.C.; Krebber, A.; Fleitz, F.J.; Brands, J.; et al. Biocatalytic asymmetric synthesis of chiral amines from ketones applied to Sitagliptin manufacture. Science 2010, 329, 305-309. [CrossRef] [PubMed]

30. Gomm, A.; Lewis, W.; Green, A.P.; O'Reilly, E. A New Generation of Smart Amine Donors for Transaminase-Mediated Biotransformations. Chem. Eur. J. 2016, 22, 12692-12695. [CrossRef] [PubMed]

31. Stekhanova, T.N.; Rakitin, A.L.; Mardanov, A.V.; Bezsudnova, E.Y.; Popov, V.O. A Novel highly thermostable branched-chain amino acid aminotransferase from the crenarchaeon Vulcanisaeta moutnovskia. Enzyme Microb. Technol. 2017, 96, 127-134. [CrossRef] [PubMed] 
32. Sayer, C.; Martinez-Torres, R.J.; Richter, N.; Isupov, M.N.; Hailes, H.C.; Littlechild, J.A.; Ward, J.M. The substrate specificity, enantioselectivity and structure of the $(R)$-selective amine: Pyruvate transaminase from Nectria haematococca. FEBS J. 2014, 281, 2240-2253. [CrossRef] [PubMed]

33. Mathew, S.; Nadarajan, S.P.; Chung, T.; Park, H.H.; Yun, H. Biochemical characterization of thermostable $\omega$-transaminase from Sphaerobacter thermophilus and its application for producing aromatic $\beta$-and $\gamma$-amino acids. Enzyme Microb. Technol. 2016, 87, 52-60. [CrossRef] [PubMed]

34. Iglesias, C.; Panizza, P.; Giordano, S.R. Identification, expression and characterization of an $R$ - $\omega$-transaminase from Caproniasemi immersa. Appl. Microbiol. Biotechnol. 2017, 101, 5677-5687. [CrossRef] [PubMed]

35. Baud, D.; Jeffries, J.W.; Moody, T.S.; Ward, J.M.; Hailes, H.C. A metagenomics approach for new biocatalyst discovery: Application to transaminases and the synthesis of allylic amines. Green Chem. 2017, 19, 1134-1143. [CrossRef]

36. Gao, S.; Su, Y.; Zhao, L.; Li, G.; Zheng, G. Characterization of a $(R)$-selective amine transaminase from Fusarium oxysporum. Process Biochem. 2017, 63, 130-136. [CrossRef]

37. Yun, H.; Cho, B.K.; Kim, B.G. Kinetic resolution of $(R, S)$-sec-butylamine using omega-transaminase from Vibrio fluvialis JS17 under reduced pressure. Biotechnol. Bioeng. 2004, 87, 772-778. [CrossRef] [PubMed]

38. Tufvesson, P.; Bach, C.; Woodley, J.M. A model to assess the feasibility of shifting reaction equilibrium by acetone removal in the transamination of ketones using 2-propylamine. Biotechnol. Bioeng. 2014, 111, 309-319. [CrossRef] [PubMed]

39. Hou, A.; Deng, Z.; Ma, H.; Liu, T. Substrate screening of amino transaminase for the synthesis of a sitagliptin intermediate. Tetrahedron 2016, 72, 4660-4664. [CrossRef]

40. Park, E.S.; Shin, J.S. Biocatalytic cascade reactions for asymmetric synthesis of aliphatic amino acids in a biphasic reaction system. J. Mol. Catal. B Enzym. 2015, 121, 9-14. [CrossRef]

41. Neto, W.; Schurmann, M.; Panella, L.; Vogel, A.; Woodley, J.M. Immobilization of-transaminase for industrial application: Screening and characterization of commercial ready to use enzyme carriers. J. Mol. Catal. B Enzym. 2015, 117, 54-61. [CrossRef]

42. Rehn, G.; Grey, C.; Branneby, C.; Lindberg, L.; Adlercreutz, P. Activity and stability of different immobilized preparations of recombinant E. coli cells containing $\omega$-transaminase. Process Biochem. 2012, 47, 1129-1134. [CrossRef]

43. Bajić, M.; Plazl, I.; Stloukal, R.; Žnidaršič-Plazl, P. Development of a miniaturized packed bed reactor with $\omega$-transaminase immobilized in LentiKats ${ }^{\circledR}$. Process Biochem. 2017, 52, 63-72. [CrossRef]

44. Satyawali, Y.; Ehimen, E.; Cauwenberghs, L.; Maesen, M.; Vandezande, P.; Dejonghe, W. Asymmetric synthesis of chiral amine in organic solvent and in-situ product recovery for process intensification: A case study. Biochem. Eng. J. 2017, 117, 97-104. [CrossRef]

45. Lalonde, J. Highly engineered biocatalysts for efficient small molecule pharmaceutical synthesis. Curr. Opin. Biotechnol. 2016, 42, 152-158. [CrossRef] [PubMed]

46. López-Iglesias, M.; González-Martínez, D.; Gotor, V.; Busto, E.; Kroutil, W.; Gotor-Fernández, V. Biocatalytic Transamination for the Asymmetric Synthesis of Pyridylalkylamines. Structural and Activity Features in the Reactivity of Transaminases. ACS Catal. 2016, 6, 4003-4009. [CrossRef]

47. Busto, E.; Simon, R.C.; Grischek, B.; Gotor-Fernández, V.; Kroutil, W. Cutting short the asymmetric synthesis of the Ramatroban precursor by employing $\omega$-Transaminases. Adv. Synth. Catal. 2014, 356, 1937-1942. [CrossRef]

48. Costa, I.C.; De Souza, R.O.; Bornscheuer, U.T. Asymmetric synthesis of serinol-monoesters catalyzed by amine transaminases. Tetrahedron Asymmetry 2017, 28, 1183-1187. [CrossRef]

49. Martin, A.R.; Shonnard, D.; Pannuri, S.; Kamat, S. Characterization ofa High Activity (S)-Aminotransferase for Substituted (S)-Aminotetralin Production: Properties and Kinetics. J. Bioprocess. Biotech. 2011, 1, 107. [CrossRef]

50. Ito, N.; Kawano, S.; Hasegawa, J.; Yasohara, Y. Purification and Characterization of a Novel (S)-Enantioselective Transaminase from Pseudomonas fluorescens KNK08-18 for the Synthesis of Optically Active Amines. Biosci. Biotechnol. Biochem. 2011, 75, 2093-2098. [CrossRef] [PubMed]

51. Voges, M.; Schmidt, F.; Wolff, D.; Sadowski, G.; Held, C. Thermodynamics of the alanine aminotransferase reaction. Fluid Ph. Equilibria 2016, 422, 87-98. [CrossRef] 
52. Seo, J.H.; Kyung, D.; Joo, K.; Lee, J.; Kim, B.G. Necessary and sufficient conditions for the asymmetric synthesis of chiral amines using $\omega$-aminotransferases. Biotechnol. Bioeng. 2011, 108, 253-263. [CrossRef] [PubMed]

53. Green, A.P.; Turner, N.J.; O’Reilly, E. Chiral amine synthesis using $\omega$-transaminases: An amine donor that displaces equilibria and enables high-throughput screening. Angew. Chem. Int. Ed. 2014, 53, 10714-10717. [CrossRef] [PubMed]

54. Richter, N.; Farnberger, J.E.; Pressnitz, D.; Lechner, H.; Zepeck, F.; Kroutil, W. A system for $\omega$-transaminase mediated $(R)$-amination using L-alanine as an amine donor. Green Chem. 2015, 17, 2952-2958. [CrossRef]

55. Martínez-Montero, L.; Gotor, V.; Gotor-Fernández, V.; Lavandera, I. Stereoselective amination of racemic sec-alcohols through sequential application of laccases and transaminases. Green Chem. 2017, 19, 474-480. [CrossRef]

56. Galman, J.L.; Slabu, I.; Weise, N.J.; Iglesias, C.; Parmeggiani, F.; Lloyd, R.C.; Turner, N.J. Biocatalytic transamination with near-stoichiometric inexpensive amine donors mediated by bifunctional mono-and di-amine transaminases. Green Chem. 2017, 19, 361-366. [CrossRef]

57. Mathew, S.; Nadarajan, S.P.; Sundaramoorthy, U.; Jeon, H.; Chung, T.; Yun, H. Biotransformation of $\beta$-keto nitriles to chiral (S)- $\beta$-amino acids using nitrilase and $\omega$-transaminase. Biotechnol. Lett. 2017, 39, 535-543. [CrossRef] [PubMed]

58. Rehn, G.; Ayres, B.; Adlercreutz, P.; Grey, C. An improved process for biocatalytic asymmetric amine synthesis by in situ product removal using a supported liquid membrane. J. Mol. Catal. B Enzym. 2016, 123, 1-7. [CrossRef]

59. Rudroff, F.; Mihovilovic, M.D.; Gröger, H.; Snajdrova, R.; Iding, H.; Bornscheuer, U.T. Opportunities and challenges for combining chemo-and biocatalysis. Nat. Catal. 2018, 1, 12-22. [CrossRef]

60. Kroutil, W.; Fischereder, E.M.; Fuchs, C.S.; Lechner, H.; Mutti, F.G.; Pressnitz, D.; Rajagopalan, A.; Sattler, J.H.; Simon, R.C.; Siirola, E. Asymmetric preparation of prim, sec-, and tert-amines employing selected biocatalysts. Org. Proc. Res. Dev. 2013, 17, 751-759. [CrossRef] [PubMed]

61. Koszelewski, D.; Pressnitz, D.; Clay, D.; Kroutil, W. Deracemization of mexiletine biocatalyzed by $\omega$-transaminases. Org. Lett. 2009, 11, 4810-4812. [CrossRef] [PubMed]

62. Chung, C.K.; Bulger, P.G.; Kosjek, B.; Belyk, K.M.; Rivera, N.; Scott, M.E.; Humphrey, G.R.; Limanto, J.; Bachert, D.C.; Emerson, K.M. Process development of C-N cross-coupling and enantioselective biocatalytic reactions for the asymmetric synthesis of niraparib. Org. Proc. Res. Dev. 2013, 18, 215-227. [CrossRef]

63. Peng, Z.; Wong, J.W.; Hansen, E.C.; Puchlopek-Dermenci, A.L.; Clarke, H.J. Development of a concise, asymmetric synthesis of a smoothened receptor (SMO) inhibitor: Enzymatic transamination of a 4-piperidinone with dynamic kinetic resolution. Org. Lett. 2014, 16, 860-863. [CrossRef] [PubMed]

64. Koszelewski, D.; Clay, D.; Rozzell, D.; Kroutil, W. Deracemisation of $\alpha$-chiral primary amines by a one-pot, two-step cascade reaction catalysed by $\omega$-transaminases. Eur. J. Org. Chem. 2009, 14, 2289-2292. [CrossRef]

65. Shin, G.; Mathew, S.; Shon, M.; Kim, B.G.; Yun, H. One-pot one-step deracemization of amines using $\omega$-transaminases. Chem. Commun. 2013, 49, 8629-8631. [CrossRef] [PubMed]

66. Steffen-Munsberg, F.; Vickers, C.; Thontowi, A.; Schätzle, S.; Tumlirsch, T.; Svedendahl-Humble, M.; Land, H.; Berglund, P.; Bornscheuer, U.T.; Höhne, M. Connecting unexplored protein crystal structures to enzymatic function. Chem CatChem 2013, 5, 150-153. [CrossRef]

67. Shin, J.S.; Kim, B.G. Exploring the Active Site of Amine: Pyruvate Aminotransferase on the Basis of the Substrate Structure-Reactivity Relationship: How the Enzyme Controls Substrate Specificity and Stereoselectivity. J. Org. Chem. 2002, 67, 2848-2853. [CrossRef] [PubMed]

68. Nobili, A.; Steffen-Munsberg, F.; Kohls, H.; Trentin, I.; Schulzke, C.; Höhne, M.; Bornscheuer, U.T. Engineering the active site of the amine transaminase from Vibrio fluvialis for the asymmetric synthesis of aryl-alkyl amines and amino alcohols. Chem CatChem 2015, 7, 757-760. [CrossRef]

69. Steffen-Munsberg, F.; Vickers, C.; Thontowi, A.; Schätzle, S.; Meinhardt, T.; Svedendahl-Humble, M.; Land, H.; Berglund, P.; Bornscheuer, U.T.; Höhne, M. Revealing the structural basis of promiscuous amine transaminase activity. ChemCatChem 2013, 5, 154-157. [CrossRef]

70. Desai, A.A. Sitagliptin manufacture: A compelling tale of green chemistry, process intensification, and industrial asymmetric catalysis. Angew. Chem. Int. Ed. 2011, 50, 1974-1976. [CrossRef] [PubMed] 
71. Midelfort, K.S.; Kumar, R.; Han, S.; Karmilowicz, M.J.; McConnell, K.; Gehlhaar, D.K.; Mistry, A.; Chang, J.S.; Anderson, M.; Villalobos, A.; et al. Redesigning and characterizing the substrate specificity and activity of Vibrio fluvialis aminotransferase for the synthesis of Imagabalin. Protein Eng. Des. Sel. 2012, 26, 25-33. [CrossRef] [PubMed]

72. Genz, M.; Melse, O.; Schmidt, S.; Vickers, C.; Dörr, M.; Van den Bergh, T.; Joosten, H.J.; Bornscheuer, U.T. Engineering the Amine Transaminase from Vibrio fluvialis towards Branched-Chain Substrates. ChemCatChem 2016, 8, 3199-3202. [CrossRef]

73. Dourado, D.F.; Pohle, S.; Carvalho, A.T.; Dheeman, D.S.; Caswell, J.M.; Skvortsov, T.; Miskelly, I.; Brown, R.T.; Quinn, D.J.; Allen, C.C.; et al. Rational Design of a (S)-Selective-Transaminase for Asymmetric Synthesis of (1S)-1-(1, 1'-biphenyl-2-yl) ethanamine. ACS Catal. 2016, 6, 7749-7759. [CrossRef]

74. Han, S.W.; Park, E.S.; Dong, J.Y.; Shin, J.S. Active-Site Engineering of $\omega$-Transaminase for Production of Unnatural Amino Acids Carrying a Side Chain Bulkier than an Ethyl Substituent. Appl. Environ. Microbiol. 2015, 81, 6994-7002. [CrossRef] [PubMed]

75. Pavlidis, I.V.; Weiß, M.S.; Genz, M.; Spurr, P.; Hanlon, S.P.; Wirz, B.; Iding, H.; Bornscheuer, U.T. Identification of (S)-selective transaminases for the asymmetric synthesis of bulky chiral amines. Nat. Chem. 2016, 8, 1076-1082. [CrossRef] [PubMed]

76. Weiß, M.S.; Pavlidis, I.V.; Spurr, P.; Hanlon, S.P.; Wirz, B.; Iding, H.; Bornscheuer, U.T. Protein-engineering of an amine transaminase for the stereoselective synthesis of a pharmaceutically relevant bicyclic amine. Org. Biomol. Chem. 2016, 14, 10249-10254. [CrossRef] [PubMed]

77. Weiß, M.S.; Pavlidis, I.V.; Spurr, P.; Hanlon, S.P.; Wirz, B.; Iding, H.; Bornscheuer, U.T. Amine Transaminase Engineering for Spatially Bulky Substrate Acceptance. ChemBioChem 2017, 18, 1022-1026. [CrossRef] [PubMed]

78. Polizzi, K.M.; Bommarius, A.S.; Broering, J.M.; Chaparro-Riggers, J.F. Stability of biocatalysts. Curr. Opin. Chem. Biol. 2007, 11, 220-225. [CrossRef] [PubMed]

79. Stepankova, V.; Bidmanova, S.; Koudelakova, T.; Prokop, Z.; Chaloupkova, R.; Damborsky, J. Strategies for stabilization of enzymes in organic solvents. ACS Catal. 2013, 3, 2823-2836. [CrossRef]

80. Littlechild, J.A. Enzymes from extreme environments and their industrial applications. Front. Bioeng. Biotechnol. 2015, 3, 161. [CrossRef] [PubMed]

81. Cerioli, L.; Planchestainer, M.; Cassidy, J.; Tessaro, D.; Paradisi, F. Characterization of a novel amine transaminase from Halomonas elongata. J. Mol. Catal. B Enzym. 2015, 120, 141-150. [CrossRef]

82. Chen, S.; Land, H.; Berglund, P.; Humble, M.S. Stabilization of an amine transaminase for biocatalysis. J. Mol. Catal. B Enzym. 2016, 124, 20-28. [CrossRef]

83. Mathew, S.; Deepankumar, K.; Shin, G.; Hong, E.Y.; Kim, B.G.; Chung, T.; Yun, H. Identification of novel thermostable $\omega$-transaminase and its application for enzymatic synthesis of chiral amines at high temperature. RSC Adv. 2016, 6, 69257-69260. [CrossRef]

84. Chen, Y.; Yi, D.; Jiang, S.; Wei, D. Identification of novel thermostable taurine-pyruvate transaminase from Geobacillus thermodenitrificans for chiral amine synthesis. Appl. Microbiol. Biotechnol. 2016, 100, 3101-3111. [CrossRef] [PubMed]

85. Ferrandi, E.E.; Previdi, A.; Bassanini, I.; Riva, S.; Peng, X.; Monti, D. Novel thermostable amine transferases from hot spring metagenomes. Appl. Microbiol. Biotechnol. 2017, 101, 4963-4979. [CrossRef] [PubMed]

86. Pannuri, S.; Kamat, S.; Venkatesh; Garcia, A.; Rogelio, M. Thermostable Omega-Transaminases. PCT Application No. WO/2006/063336.15 June 2006.

87. Sayer, C.; Isupov, M.N.; Westlake, A.; Littlechild, J.A. Structural studies of Pseudomonas and Chromobacterium $\omega$-aminotransferases provide insights into their differing substrate specificity. Acta Crystallogr. D Biol. Crystallogr. 2013, 69, 564-576. [CrossRef] [PubMed]

88. Börner, T.; Rämisch, S.; Reddem, E.R.; Bartsch, S.; Vogel, A.; Thunnissen, A.M.; Adlercreutz, P.; Grey, C. Explaining Operational Instability of Amine Transaminases: Substrate-Induced Inactivation Mechanism and Influence of Quaternary Structure on Enzyme-Cofactor Intermediate Stability. ACS Catal. 2017, 7, 1259-1269. [CrossRef]

89. Börner, T.; Rämisch, S.; Bartsch, S.; Vogel, A.; Adlercreutz, P.; Grey, C. Three In One Go: Thermo-, Solvent and Catalytic Stability by Engineering the Cofactor-Binding Element of Amine Transaminases. ChemBioChem 2017, 18, 1482-1486. [CrossRef] [PubMed] 
90. Huang, J.; Xie, D.F.; Feng, Y. Engineering thermostable (R)-selective amine transaminase from Aspergillus terreus through in silico design employing B-factor and folding free energy calculations. Biochem. Biophys. Res. Commun. 2017, 483, 397-402. [CrossRef] [PubMed]

91. Deepankumar, K.; Nadarajan, S.P.; Mathew, S.; Lee, S.G.; Yoo, T.H.; Hong, E.Y.; Kim, B.G.; Yun, H. Engineering Transaminase for Stability Enhancement and Site-Specific Immobilization through Multiple Noncanonical Amino Acids Incorporation. ChemCatChem 2015, 7, 417-421. [CrossRef]

92. Deepankumar, K.; Shon, M.; Nadarajan, S.P.; Shin, G.; Mathew, S.; Ayyadurai, N.; Kim, B.G.; Choi, S.H.; Lee, S.H.; Yun, H. Enhancing Thermostability and Organic Solvent Tolerance of $\omega$-Transaminase through Global Incorporation of Fluorotyrosine. Adv. Synth. Catal. 2014, 356, 993-998. [CrossRef]

93. Patil, M.D.; Dev, M.J.; Shinde, A.S.; Bhilare, K.D.; Patel, G.; Chisti, Y.; Banerjee, U.C. Surfactant-mediated permeabilization of Pseudomonas putida KT2440 and use of the immobilized permeabilized cells in biotransformation. Process Biochem. 2017, 63, 113-121. [CrossRef]

94. Yewale, T.; Singhal, R.S.; Vaidya, A.A. Immobilization of inulinase from Aspergillus niger NCIM 945 on chitosan and its application in continuous inulin hydrolysis. Biocatal. Agric. Biotechnol. 2013, 2, 96-101. [CrossRef]

95. Koszelewski, D.; Müller, N.; Schrittwieser, J.H.; Faber, K.; Kroutil, W. Immobilization of $\omega$-transaminases by encapsulation in a sol-gel/celite matrix. J. Mol. Catal. B Enzym. 2010, 63, 39-44. [CrossRef]

96. Mallin, H.; Menyes, U.; Vorhaben, T.; Höhne, M.; Bornscheuer, U.T. Immobilization of two (R)-Amine Transaminases on an Optimized Chitosan Support for the Enzymatic Synthesis of Optically Pure Amines. ChemCatChem 2013, 5, 588-593. [CrossRef]

97. Mallin, H.; Höhne, M.; Bornscheuer, U.T. Immobilization of (R)-and (S)-amine transaminases on chitosan support and their application for amine synthesis using isopropylamine as donor. J. Biotechnol. 2014, 191, 32-37. [CrossRef] [PubMed]

98. Truppo, M.D.; Strotman, H.; Hughes, G. Development of an immobilized transaminase capable of operating in organic solvent. ChemCatChem 2012, 4, 1071-1074. [CrossRef]

99. Yi, S.S.; Lee, C.W.; Kim, J.; Kyung, D.; Kim, B.G.; Lee, Y.S. Covalent immobilization of $\omega$-transaminase from Vibrio fluvialis JS17 on chitosan beads. Process Biochem. 2007, 42, 895-898. [CrossRef]

100. De Souza, S.P., II; Silva, G.M.; Miranda, L.S.; Santiago, M.F.; Lam, F.L.; Dawood, A.; Bornscheuer, U.T.; De Souza, R.O. Cellulose as an efficient matrix for lipase and transaminase immobilization. RSC Adv. 2016, 6, 6665-6671. [CrossRef]

101. Cárdenas-Fernández, M.; Neto, W.; López, C.; Alvaro, G.; Tufvesson, P.; Woodley, J.M. Immobilization of Escherichia coli containing $\omega$-transaminase activity in LentiKats ${ }^{\circledR}$. Biotechnol. Prog. 2012, 28, 693-698. [CrossRef] [PubMed]

102. Matosevic, S.; Lye, G.J.; Baganz, F. Immobilised enzyme microreactor for screening of multi-step bioconversions: Characterisation of a de novo transketolase- $\omega$-transaminase pathway to synthesise chiral amino alcohols. J. Biotechnol. 2011, 155, 320-329. [CrossRef] [PubMed]

103. Halim, A.A.; Szita, N.; Baganz, F. Characterization and multi-step transketolase- $\omega$-transaminase bioconversions in an immobilized enzyme microreactor (IEMR) with packed tube. J. Biotechnol. 2013, 168, 567-575. [CrossRef] [PubMed]

104. Yang, J.; Ni, K.; Wei, D.; Ren, Y. One-step purification and immobilization of his-tagged protein via $\mathrm{Ni}^{2+}$-functionalized $\mathrm{Fe}_{3} \mathrm{O}_{4} @$ polydopamine magnetic nanoparticles. Biotechnol. Bioprocess Eng. 2015, 20, 901-907. [CrossRef]

105. Jia, H.; Huang, F.; Gao, Z.; Zhong, C.; Zhou, H.; Jiang, M.; Wei, P. Immobilization of $\omega$-transaminase by magnetic PVA- $\mathrm{Fe}_{3} \mathrm{O}_{4}$ nanoparticles. Biotechnol. Rep. 2016, 10, 49-55. [CrossRef] [PubMed]

106. Sun, J.; Cui, W.H.; Du, K.; Gao, Q.; Du, M.; Ji, P.; Feng, W. Immobilization of R-w-transaminase on $\mathrm{MnO}_{2}$ nanorods for catalyzing the conversion of $(R)-1$-phenylethylamine. J. Biotechnol. 2017, 245, 14-20. [CrossRef] [PubMed]

107. Sperl, J.M.; Sieber, V. Multienzyme Cascade Reactions- Status and Recent Advances. ACS Catal. 2018, 8, 2385-2396. [CrossRef]

108. Ahsan, M.M.; Jeon, H.; Nadarajan, S.P.; Chung, T.; Yoo, H.W.; Kim, B.G.; Patil, M.D.; Yun, H. Biosynthesis of the Nylon 12 Monomer, $\omega$-Aminododecanoic Acid with Novel CYP153A, AlkJ, and $\omega$-TA Enzymes. Biotechnol. J. 2018, 13, 1700562. [CrossRef] [PubMed] 
109. Ahsan, M.M.; Sung, S.; Jeon, H.; Patil, M.D.; Chung T Yun, H. Biosynthesis of Medium-to Long-Chain $\alpha$, $\omega$-Diols from Free Fatty Acids Using CYP153A Monooxygenase, Carboxylic Acid Reductase, and E. coli Endogenous Aldehyde Reductases. Catalysts 2017, 8, 4. [CrossRef]

110. Simon, R.C.; Richter, N.; Busto, E.; Kroutil, W. Recent developments of cascade reactions involving $\omega$-transaminases. ACS Catal. 2013, 4, 129-143. [CrossRef]

111. Hepworth, L.J.; France, S.P.; Hussain, S.; Both, P.; Turner, N.J.; Flitsch, S.L. Enzyme cascades in whole cells for the synthesis of chiral cyclic amines. ACS Catal. 2017, 7, 2920-2925. [CrossRef]

112. Fuchs, M.; Farnberger, J.E.; Kroutil, W. The industrial age of biocatalytic transamination. Eur. J. Org. Chem. 2015, 32, 6965-6982. [CrossRef] [PubMed]

113. France, S.P.; Hepworth, L.J.; Turner, N.J.; Flitsch, S.L. Constructing biocatalytic cascades: In vitro and in vivo approaches to de novo multi-enzyme pathways. ACS Catal. 2016, 7, 710-724. [CrossRef]

114. Fuchs, M.; Tauber, K.; Sattler, J.; Lechner, H.; Pfeffer, J.; Kroutil, W.; Faber, K. Amination of benzylic and cinnamic alcohols via a biocatalytic, aerobic, oxidation-transamination cascade. RSC Adv. 2012, 2, 6262-6265. [CrossRef]

115. Palacio, C.M.; Crismaru, C.G.; Bartsch, S.; Navickas, V.; Ditrich, K.; Breuer, M.; Abu, R.; Woodley, J.M.; Baldenius, K.; Wu, B.; et al. Enzymatic network for production of ether amines from alcohols. Biotechnol. Bioeng. 2016, 113, 1853-1861. [CrossRef] [PubMed]

116. Birrell, J.A.; Jacobsen, E.N. A Practical method for the synthesis of highly enantioenriched trans-1, 2-amino alcohols. Org. Lett. 2013, 15, 2895-2897. [CrossRef] [PubMed]

117. Gruber, P.; Carvalho, F.; Marques, M.P.; O'Sullivan, B.; Subrizi, F.; Dobrijevic, D.; Ward, J.; Hailes, H.C.; Fernandes, P.; Wohlgemuth, R.; et al. Enzymatic synthesis of chiral amino-alcohols by coupling transketolase and transaminase-catalyzed reactions in a cascading continuous-flow microreactor system. Biotechnol. Bioeng. 2018, 115, 586-596. [CrossRef] [PubMed]

118. Erdmann, V.; Lichman, B.R.; Zhao, J.; Simon, R.C.; Kroutil, W.; Ward, J.M.; Hailes, H.C.; Rother, D. Enzymatic and Chemoenzymatic Three-Step Cascades for the Synthesis of Stereochemically Complementary Trisubstituted Tetrahydroisoquinolines. Angew. Chem. Int. Ed. 2017, 56, 12503-12507. [CrossRef] [PubMed]

119. Fischereder, E.M.; Pressnitz, D.; Kroutil, W. Stereoselective Cascade to C3-methylated strictosidine derivatives employing transaminases and strictosidine synthases. ACS Catal. 2015, 6, 23-30. [CrossRef]

120. Turner, N.J.; Kumar, R. Editorial overview: Biocatalysis and biotransformation: The golden age of biocatalysis. Curr. Opin. Chem. Biol. 2018, 43, A1-A3. [CrossRef] [PubMed] 